\title{
Groei en productie van zwarte els in Nederland
}

J.J. Jansen ${ }^{1}$, A. Oosterbaan ${ }^{2}$, G.M.J. Mohren ${ }^{1}$, P. Copini ${ }^{2}$ en J. den Ouden ${ }^{1}$

FEM Groei en Productie Rapport 2018-10

WAGENINGEN

UNIVERSITY \& RESEARCH

$\begin{array}{ll}1 & \text { Forest Ecology and Forest Management group, Wageningen University, Department of Environmental Sciences } \\ 2 & \text { Wageningen Environmental Research (WENR) }\end{array}$ 
Jansen, J.J., A. Oosterbaan, G.M.J. Mohren. P. Copini en J. den Ouden, 2018. Groei en productie van zwarte els in Nederland. FEM Groei en Productie Rapport 2018-10, 47 blz.

Synopsis: Van 1965 tot 1990 is in Nederland op bescheiden schaal groei- en productieonderzoek bij de zwarte els uitgevoerd. Dat betreffen twee studies van de Dorschkamp/IBN. Samen met de permanente steekproeven uit de HOSP zijn 14 proefperken met 59 opnamen beschikbaar. Daarnaast waren er de gegevens van 518 opstanden uit de $4^{\mathrm{e}}$ Bosstatistiek.

Voor de ontwikkeling van de opperhoogte $h_{\text {top }}$ met de leeftijd $t$ werd het heteromorfe model van Jansen et al. gekozen, met asymptoot en 4 andere parameters. Als site index is voor de $h_{50}$ gekozen. De diameter bij een hoogte van $7 \mathrm{~m}\left(d_{7}\right)$ geschat met data uit de $4{ }^{\mathrm{e}}$ Bosstatistiek, voor de groei tot $d_{7}$ werd een powerfunctie in $h_{\text {top }}$ gebruikt.

Met een powerfunctie werd de grondvlakbijgroei $i_{G}$ verklaard met leeftijd, $t$ en standruimte index van Hart $S \%$. Voor $S \%>15.7$ daalt de grondvlakbijgroei met een niet-lineaire functie in $S \%$.

Het effect van de dunning op de diameter na dunning is gemodelleerd met het La Bastide-Faber model. Er is een opbrengsttabel gemaakt met een matige laagdunning en vijf boniteiten.

Abstract: In the Netherlands growth and yield research on black alder was done on a limited scale from 1965 to 1990. This regards two studies by the Dorschkamp/IBN research institute; together with the permanent sample plots from the timber prognosis system HOSP, this comprises a dataset of 14 plots with 59 recordings. In addition, the information from 518 stands of the Fourth National Forest Inventory was used.

For the development of top height $h_{\text {top }}$ with age $t$ Jansen's et al. polymorphic model with site index $h_{50}$ and four additional parameters fitted best.

The diameter at a height of $7 \mathrm{~m}\left(d_{7}\right)$ was estimated from data of the Fourth National Forest Inventory. The diameter development up to stand height of $7 \mathrm{~m}$ was described with a model of Jansen et al., a power function in $h_{\text {top }}$ and the estimated value for $d_{7}$. From a stand height of $7 \mathrm{~m}$ upwards, the basal area increment $\left(i_{G}\right)$ was also described by Jansen's et al. model based on a power function with $t$, year of recording (yor), and the stand density of Hart ( $S \%)$. For $S \%>15.7$ the basal area increment decreases non-linear with increasing $S \%$. The model contains a correction factor for yor, although this was not significant, as the year of recording (yor), turned out to be not significant. The effect of thinning on the diameter after thinning was modelled with the La Bastide-Faber model.

The models were used to construct a yield table with five site classes and one thinning intensity.

Keywords: Black alder, Alnus glutinosa, Netherlands, yield table, different thinning grade, BeckingHart spacing index, height growth models, power model for basal area increment, La Bastide-Faber model for thinning effect.

Dit rapport is gratis te downloaden op: https://doi.org/10.18174/444099

Dit rapport is gebaseerd op de database: Goudzwaard, L., J.J. Jansen, A. Oosterbaan, J.F. Oldenburger, G.M.J. Mohren \& J. den Ouden, 2016. FEM growth and yield data Monocultures - other species. DANS. http://dx.doi.org/10.17026/dans-xc2-f34x 


\section{Voorwoord}

In Nederland zijn er waarnemingen verricht in permanente proefperken van de zwarte els (Alnus glutinosa) tussen 1965 en 1990.

Jansen et al. (1996) nemen in hun tabellenboek een bewerking van de tabel van Mitscherlich (1945) op voor de zwarte els. Bartelink et al. (2001) geven een uitgebreid overzicht van de context en publicaties van het groei- en productieonderzoek aan deze en andere boomsoorten in Nederland.

Samen met de permanente steekproefpunten van de HOSP is er de huidige studie de beschikking over de gegevens van 12 plots met 39 opnamen in het tijdvak 1965 tot 1998. Daarnaast zijn er de gegevens van eenmalige opnamen uit de $4^{\mathrm{e}}$ Bosstatistiek in 518 monoculturen van zwarte els.

In dit rapport wordt de ontwikkeling van opstanden van zwarte els met verschillende dunninggraden geanalyseerd met het doel een groeimodel te maken bij een ruim scala aan beheerstrategieën. Deze studie is de twaalfde in een serie, waarin de groei en productie van douglas (Jansen et al., 2016), Japanse lariks, fijnspar, zomereik, populier, grove den, beuk, Corsicaanse den, Oostenrijkse den, Amerikaanse eik en es werden bestudeerd.

De studie volgt waar mogelijk dezelfde werkwijze als de voorgaande studies en vaak zijn delen van de tekst uit deze rapporten (soms ook zonder bronvermelding) overgenomen. Maar vanaf de Amerikaanse eik en volgende rapporten is er sprake van een vereenvoudigde werkwijze, omdat er beduidend minder gegevens ter beschikking zijn en wordt er ook een opbrengsttabel met één dunninggraad gepresenteerd.

Om de toegankelijkheid voor niet Nederlandse lezer te verhogen zijn alle figuren, en formules en veel tabellen van Engelse tekst voorzien.

Hans Jansen,

Wageningen, 2018 


\section{Inhoud}

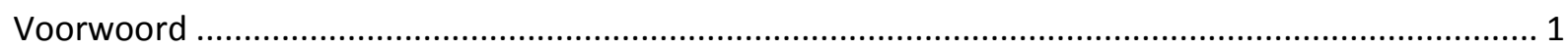

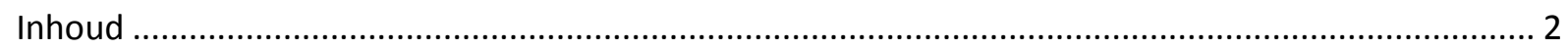

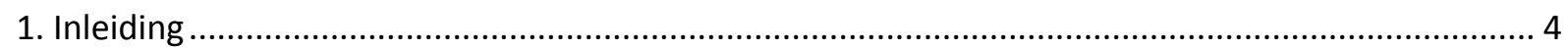

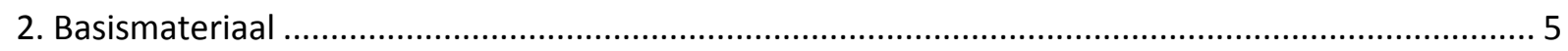

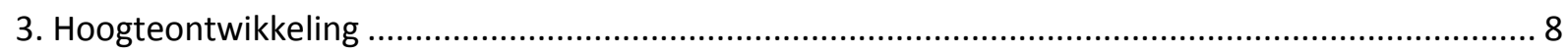

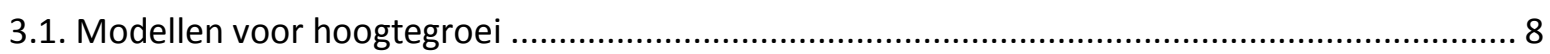

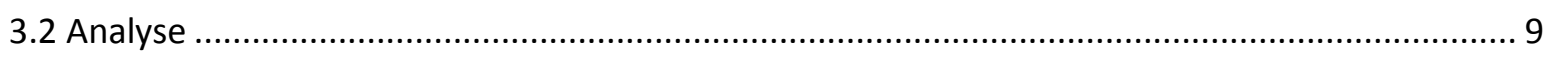

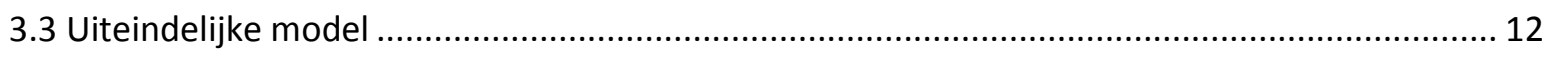

3.3.1 Analyse van de residuen bij de permanente plots ................................................ 13

3.3.2 Boniteitindeling ............................................................................................... 14

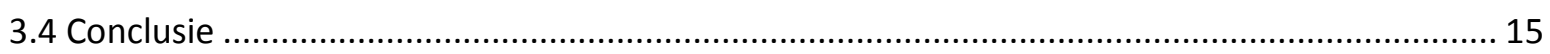

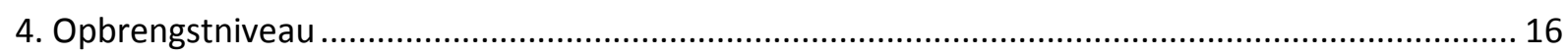

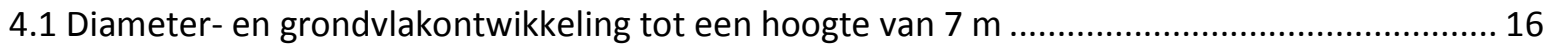

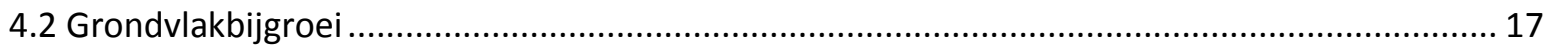

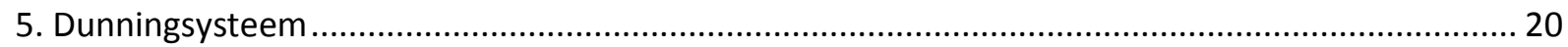

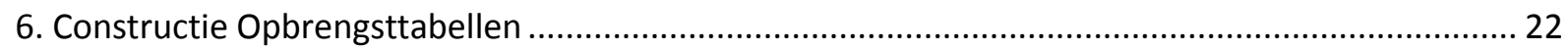

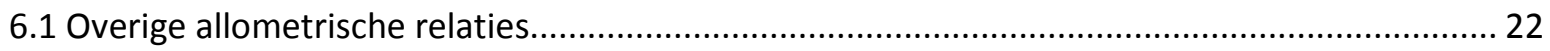

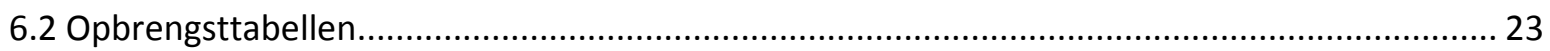

6.3 Vergelijking met andere opbrengsttabellen .................................................................. 25

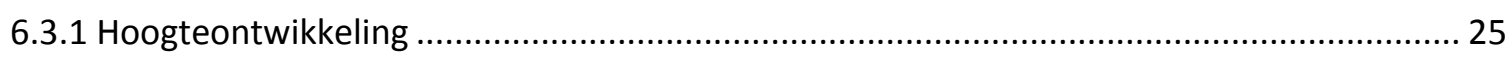

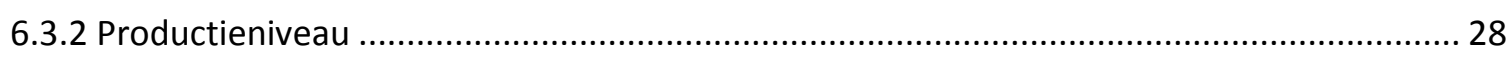

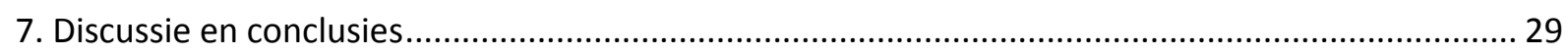

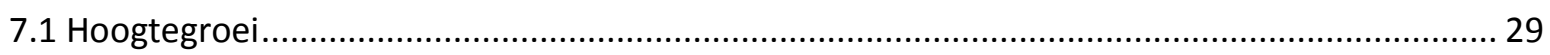

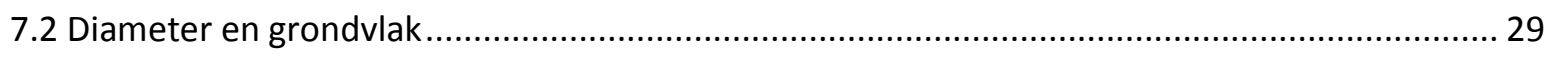

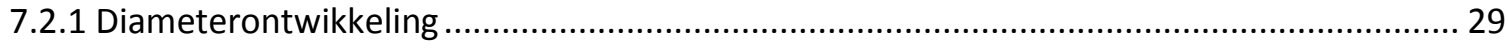

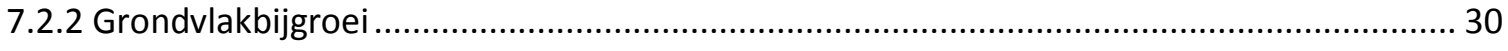

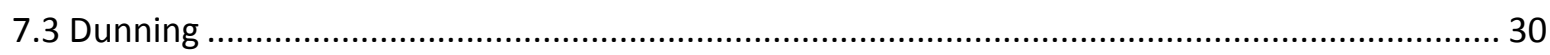

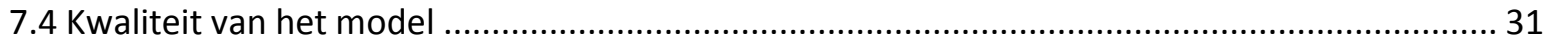

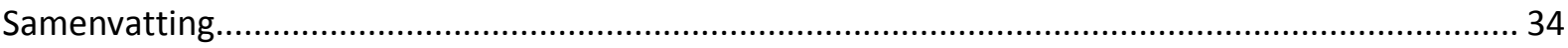

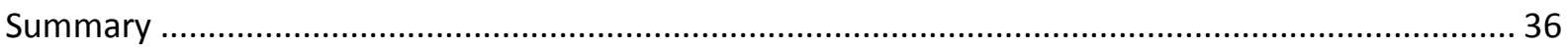

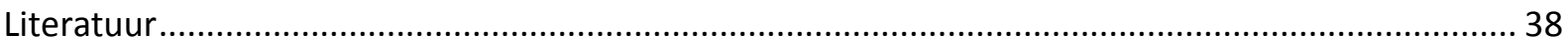

Bijlage 1. Opbrengsttabel voor zwarte els Nederland 2018 ..................................................... 40

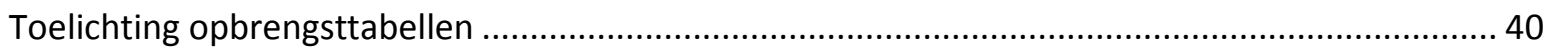


Explanation yield tables

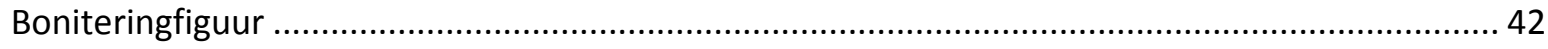

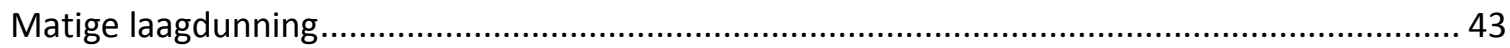




\section{Inleiding}

Tussen 1965 en 1998 zijn er gegevens verzameld over de groei van zwarte els. Met deze gegevens is het mogelijk modellen te maken die de ontwikkeling van zwarte elzenopstanden bij een variatie aan beheerstrategieën verklaren en mogelijk voorspellen. Eén van de gebruikelijke modellen is een opbrengsttabel. Jansen et al. (1996) hebben een opbrengsttabel voor de zwarte els opgenomen dat betreft een OPTAB-simulatie van de tabel van Mitscherlich (1945) voor Duitsland.

Een opbrengsttabel is een model waarmee de opstandontwikkeling in de tijd wordt beschreven en het bestaat meestal uit drie submodellen:

1. Model voor de hoogteontwikkeling, dit wordt In Hoofdstuk 3 besproken.

2. Model voor de grondvlakbijgroei in de tijd of relatief ten opzichte van de hoogte, waarmee het productieniveau van opstanden kan worden voorspeld, dit wordt In Hoofdstuk 4 besproken.

3. Model voor de dunning. Dit model moet een definitie geven van de dunninggraden, daarnaast is het de vraag wat de interactie is met model ad 2 bij verschillende dunninggraden. In Hoofdstuk 5 komen deze vragen aan de orde.

In hoofdstuk 2 worden de basisgegevens besproken. In Hoofdstuk 6 worden de 3 submodellen geïntegreerd tot een serie opbrengsttabellen. Deze worden vergeleken met andere tabellen. De opbrengsttabellen zijn te vinden in Bijlage 1. 


\section{Basismateriaal}

Sinds 1965 is er in Nederland op zeer bescheiden schaal onderzoek gedaan naar de ontwikkeling van zwarte elzenopstanden (Alnus glutinosa) dit betref één studie, gedurende een deels overlappende periode zijn ook steekproefpunten van de HOSP gemonitord:

2. Groei- en productieonderzoek Dorschkamp/IBN 1965 - 1990 ten behoeve van opbrengsttabellen. Er zijn 2 proefperken met 8 opnamen;

3. Herkomstproef IBN 1968 - 1986, dit proefperk B52 bij Lelystad wordt zowel door Verweij (1983) als Van der Werf (1986) vermeld. Hieruit is de hoogteontwikkeling voor twee herkomsten afgeleid met beide 10 opnamen, zie Tabel 2 voor de data;

4. HOSP 1984 -1998, in beheer bij Probos. Dit zijn ca. 3000 permanente steekproefpunten uit de 4e bosstatistiek. Hieruit zijn 10 monocultures met zwarte els geselecteerd met in totaal 31 opnamen.

In totaal gaat het om 59 opnamen in 14 proefperken.

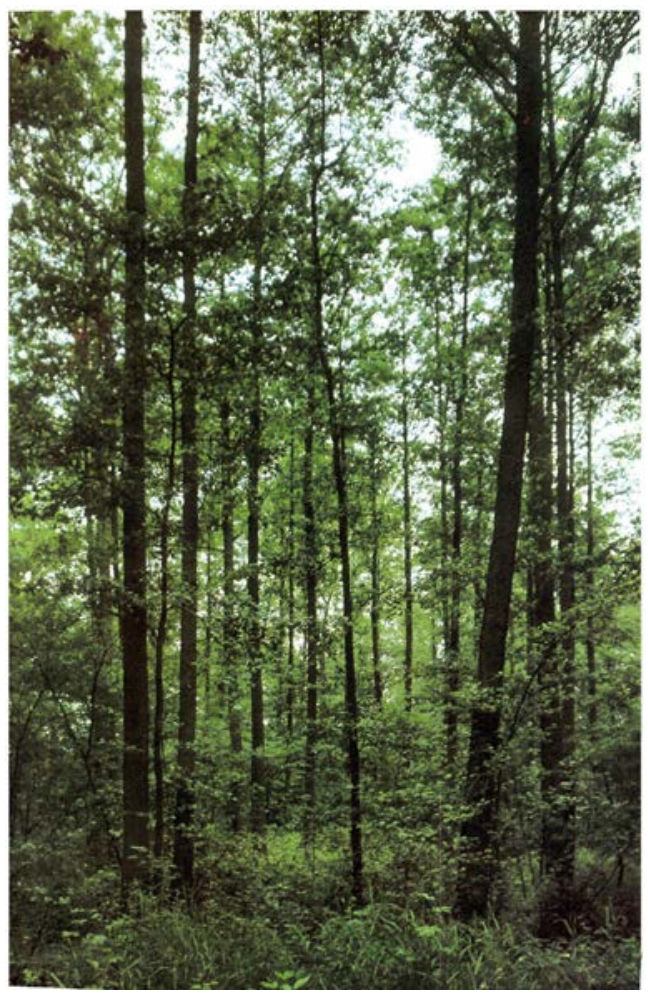

De proefvelden van studie 2 betreffen proefvakken met een vaste oppervlakte.

Het proefperk 1 op Singraven stond model voor de mogelijkheden van de snelle groei van de zwarte els met een foto van J.B.W. Weg in Houtsoorten voor nieuwe bossen in Nederland (van Goor et al., 1969), zie kopie van de foto hiernaast.

In studie 4 gaat het om vaste steekproefpunten met een variërende straal zodanig dat er minimaal 25 bomen in de steekproef liggen. Door kap of ingroei kan deze wijzigen. Alleen dat deel wat in alle opnamen aanwezig was is bij het onderzoek betrokken.

Voor het bepalen van de dunninggraad is het S-procent van Hart (1928) (ook bekend als de Hart-Becking Spacing Index) van alle perken en opnamen berekend met formule (1):

$$
S \%=\frac{a_{a t}}{h_{\text {top }}} \cdot 100=\frac{100}{h_{\text {top }}} \cdot \sqrt{\frac{10000}{N_{a t}} \cdot \frac{2}{\sqrt{3}}} \approx \frac{10745.7}{h_{\text {top }} \cdot \sqrt{N_{a t}}}
$$

In deze definitie is de gemiddelde boomafstand na dunning $\left(a_{a t}\right)$ bepaald met een regelmatig driehoekverband. Het symbool $h_{\text {top }}$ staat voor de opperhoogte.

Van alle proefperken zijn basisgegevens als oppervlakte, kiemjaar en ligging bekend.

De afzonderlijke metingen en berekeningen aan de bomen in de proefperken vormen de basisgegevens. Deze zijn daarna geaggregeerd tot kenmerken per ha per proefperk van voor, na, en van de dunning. De boomgegevens spelen in deze studie alleen een rol om de opstandkenmerken te genereren. 
Per proefperk en opname zijn de gegevens beschikbaar, zoals vermeld in Tabel 1 . Voor een volledige beschrijving van gemeten en berekende gegevens zie de file "Read me - FEM growth and yield data Monocultures - Other species.pdf" in de database FEM growth and yield data Monocultures - Other species (Goudzwaard et al., 2016).

Tabel 1. Basisgegevens per plot en opname.

Table 1. Base information per plot and recording

\begin{tabular}{|c|c|c|}
\hline Naam & Symbool & Betekenis \\
\hline plotnr & & Plotnummer \\
\hline study & & Studienummer \\
\hline region & & Regio \\
\hline area & & Plotoppervlakte in ha \\
\hline yog & & Kiemjaar \\
\hline NO & $N_{0}$ & Beginstamtal \\
\hline sperc & $S \%$ & gemiddelde Hart-Becking Spacing Index in plot \\
\hline sperc0 & $S_{0} \%$ & Actuele Hart-Becking Spacing Index in de opname \\
\hline nrec & & Aantal opnamen \\
\hline rec & & Opname nummer \\
\hline DOR & & Datum van de opname \\
\hline age & $t$ & Leeftijd in jr \\
\hline htop & $h_{\text {top }}$ & Opperhoogte in $\mathrm{m}$ \\
\hline hdom & $h_{\text {dom }}$ & Dominante hoogte in $\mathrm{m}$ \\
\hline ddom & $d_{d o m}$ & Diameter van de dominante hoogte boom in $\mathrm{cm}$ \\
\hline N_bt & $N_{b t}$ & Stamtal per ha voor dunning \\
\hline G_bt & $G_{b t}$ & Grondvlak voor dunning in $\mathrm{m}^{2} / \mathrm{ha}$ \\
\hline h_bt & $h_{b t}$ & Hoogte van de grondvlak-middenstam in m voor dunning \\
\hline dg_bt & $d_{b t}$ & Diameter van de grondvlak-middenstam in $\mathrm{cm}$ voor dunning \\
\hline V_bt & $V_{b t}$ & Volume voor dunning in $\mathrm{m}^{3} / \mathrm{ha}$ \\
\hline N_th & $N_{t h}$ & Stamtal per ha van de dunning \\
\hline G_th & $G_{t h}$ & Grondvlak van de dunning in $\mathrm{m}^{2} / \mathrm{ha}$ \\
\hline h_th & $h_{t h}$ & Hoogte van de grondvlak-middenstam in m van de dunning \\
\hline dg_th & $d_{t h}$ & Diameter van de grondvlak-middenstam in $\mathrm{cm}$ van de dunning \\
\hline V_th & $V_{t h}$ & Volume van de dunning in $\mathrm{m}^{3} /$ ha \\
\hline N_at & $N_{a t}$ & Stamtal per ha na dunning \\
\hline G_at & $G_{a t}$ & Grondvlak na dunning in $\mathrm{m}^{2} / \mathrm{ha}$ \\
\hline h_at & $h_{a t}$ & Hoogte van de grondvlak-middenstam in m na dunning \\
\hline dg_at & $d_{a t}$ & Diameter van de grondvlak-middenstam in cm na dunning \\
\hline V_at & $V_{a t}$ & Volume na dunning in $\mathrm{m}^{3} / \mathrm{ha}$ \\
\hline
\end{tabular}

Verweij (1983) en Van der Werf (1986) geven voor de data uit studie 3 staafdiagrammen met de gemiddelde hoogte voor twee herkomsten, deze zijn gedigitaliseerd en de gemiddelde hoogte is bepaald. Met de inverse van Formule (16) die later in Paragraaf 6.1 is afgeleid, is vervolgens de opperhoogte geschat, zie Tabel 2. 
Tabel 2. Gegevens proefperk B52 met geschatte opperhoogte.

Table 2. Data provenance trial B52 with estimated top height.

\begin{tabular}{|lllrrrr|}
\hline plotnr & plotcode & name & rec & age & $\boldsymbol{h}_{\boldsymbol{m}}$ & $\boldsymbol{h}_{\text {top }}$ \\
\hline 13 & B52A & 14 - Singraven & 1 & 2 & 0.5 & 0.6 \\
13 & B52A & 14 - Singraven & 2 & 5 & 2.9 & 3.6 \\
13 & B52A & 14 - Singraven & 3 & 6 & 3.8 & 4.8 \\
13 & B52A & 14 - Singraven & 4 & 7 & 4.8 & 5.9 \\
13 & B52A & 14 - Singraven & 5 & 8 & 5.7 & 6.9 \\
13 & B52A & 14 - Singraven & 6 & 9 & 6.5 & 7.8 \\
13 & B52A & 14 - Singraven & 7 & 10 & 7.1 & 8.4 \\
13 & B52A & 14 - Singraven & 8 & 14 & 9.5 & 10.9 \\
13 & B52A & $14-$ Singraven & 9 & 15 & 10.3 & 11.7 \\
13 & B52A & 14 - Singraven & 10 & 20 & 12.6 & 14.0 \\
14 & B52B & 16 - Erdmannshausen & 1 & 2 & 0.8 & 1.0 \\
14 & B52B & 16 - Erdmannshausen & 2 & 5 & 3.9 & 4.9 \\
14 & B52B & 16 - Erdmannshausen & 3 & 6 & 4.8 & 5.9 \\
14 & B52B & 16 - Erdmannshausen & 4 & 7 & 5.5 & 6.7 \\
14 & B52B & 16 - Erdmannshausen & 5 & 8 & 6.4 & 7.7 \\
14 & B52B & 16 - Erdmannshausen & 6 & 9 & 6.9 & 8.2 \\
14 & B52B & 16 - Erdmannshausen & 7 & 10 & 7.6 & 8.9 \\
14 & B52B & 16 - Erdmannshausen & 8 & 14 & 8.7 & 10.1 \\
14 & B52B & 16 - Erdmannshausen & 9 & 15 & 10.1 & 11.5 \\
14 & B52B & 16 - Erdmannshausen & 10 & 20 & 11.7 & 13.1 \\
\hline
\end{tabular}




\section{Hoogteontwikkeling}

Voor de hoogteontwikkeling zijn er 14 proef- en steekproefperken met 59 opnamen beschikbaar voor analyse (zie Figuur 1a). Daarnaast is er beschikking over de hoogtegegevens van 518 opstanden uit de $4^{\mathrm{e}}$ Bosstatistiek (zie Figuur $1 \mathrm{~b}$ ).
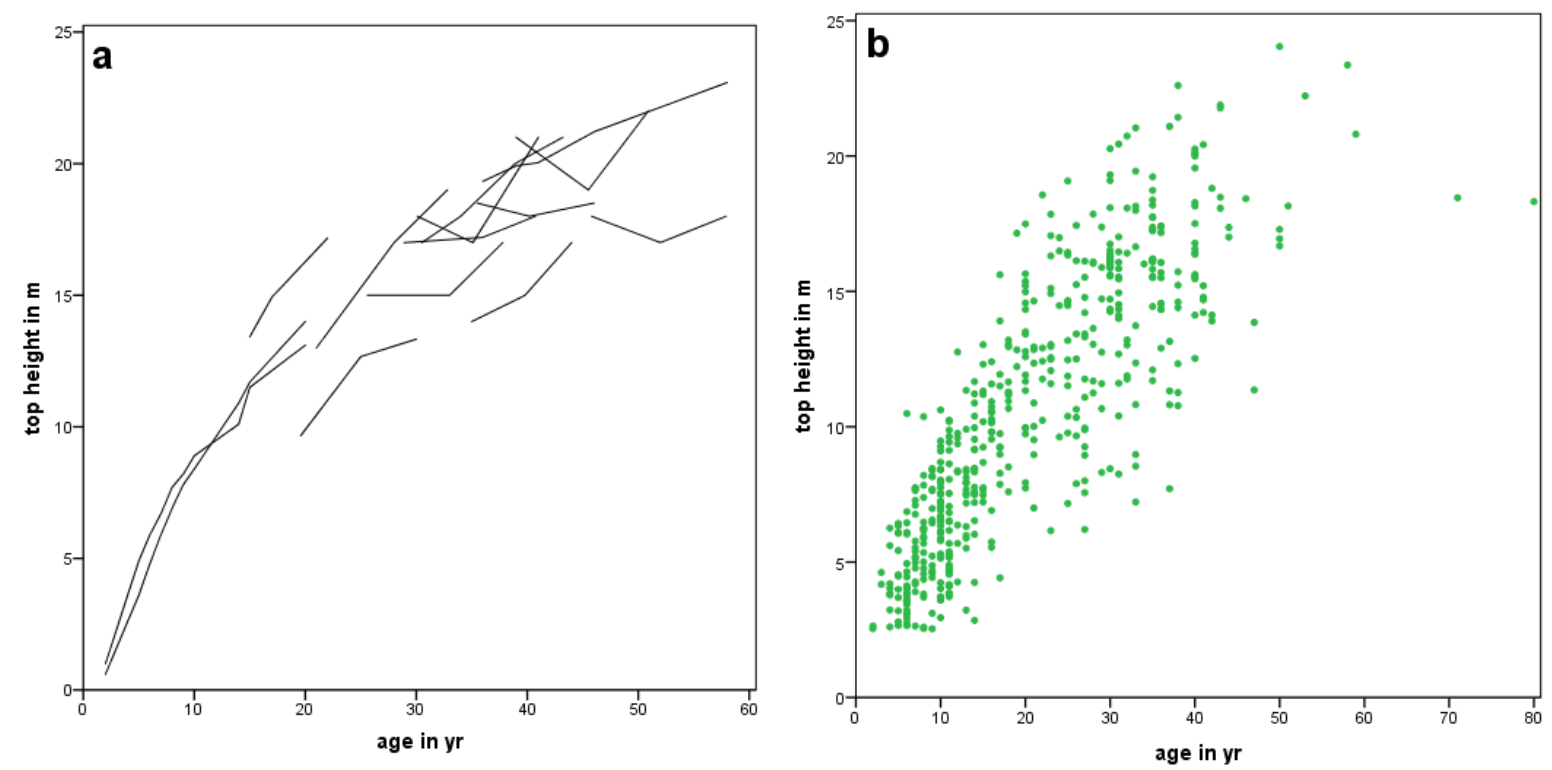

Figuur 1. Hoogteontwikkeling in de proefperken in Nederland (a) en hoogte en leeftijd bij waarnemingen in $4^{e}$ Bosstatistiek (b).

Figure 1. Development of tree height in plots in the Netherlands (a) and height and age at data from Fourth Dutch Forest Inventory (b).

Het is duidelijk dat de range in leeftijd en hoogte van de proefperken maar een zeer klein deel van de totale range in het Nederlandse bos beslaat.

\subsection{Modellen voor hoogtegroei}

In de opbrengsttabellen tot ongeveer 1970 is de hoogteontwikkeling meestal handmatig gefit. Vanaf 1970 worden over het algemeen niet-lineaire groeifuncties gebruikt om de hoogteontwikkeling te fitten. In de huidige Nederlandse opbrengsttabellen (Jansen et al., 1996) is meestal het Chapman-Richards model gebruikt:

$$
h_{\text {top }}=S \cdot\left(1-e^{-a \cdot t}\right)^{b}
$$

In Formule (2) is $S$ de zogenaamde "site index" de proefperkspecifieke constante en de asymptoot in het model. Deze $S$ kan gezien worden als de afplattingshoogte en het is tevens een maat voor de boniteit, in dit geval een absolute hoogteboniteit. Daarnaast wordt ook de hoogte bij een vaste leeftijd als maat voor de boniteit gebruikt. Voor de zwarte els zal de $h_{50}$ worden gebruikt

De te onderzoeken modellen zijn Chapman-Richards, Burkhart \& Tennent, Jansen \& Hildebrand en Cieszewski., zie Paragraaf 3.2 voor formules en referenties. 
Jansen et al. (2018) ontwikkelde een selectiemethode voor een model in twee stappen. Als eerste een werd een MCA (Multi criteria-analyse) gebruik met 7 criteria. Daarna een visuele test met de data van de $4^{\mathrm{e}}$ bosstatistiek. De 7 criteria betreffen:

1. De algemene maat voor de verklaring, hiervoor is $R^{2}$ adj gebruikt;

2. De kwaliteit van de schatter van boniteit-parameters door naar de variatiecoëfficiënt $C V$ ervan te kijken. Indien het model voor alle proefperken geschikt is, zal het $95 \%$ betrouwbaarheidsinterval van CV klein zijn;

3. De $h_{50}$ met de gemiddelde waarde en interval, volgens Figuur $1 \mathrm{~b}$ moet dat gemiddelde ongeveer $20 \mathrm{~m}$ zijn en tussen de 16 en $24 \mathrm{~m}$ liggen, maar erg nauwkeurig is dit niet vast te stellen;

4. De model-parameter $S$ en een $95 \%$ betrouwbaarheidsinterval ervan, en getoetst of deze overeenkomt met de te verwachten maximale afplattingshoogte. De hoogst gemeten opperhoogte in de permanente plots bleek $23.1 \mathrm{~m}$ bij een leeftijd van $58 \mathrm{jr}$. en in de 4e bosstatistiek (CBS, 1985) was dat $24 \mathrm{~m}$ bij $50 \mathrm{jr}$. Volgens https://www.monumentaltrees.com/nl/bomen/alnusglutinosa/records/ (geraadpleegd op 03-01-2018) zijn individuele zwarte elzen in Nederland niet hoger dan $33 \mathrm{~m}$ en in Oost-Europa is dat hoger tot $39 \mathrm{~m}$. Ook Claessens et al. (2010) bevestigen beeld. De maximale $S$-waarde voor de beste boniteit voor de zwarte els in Nederland zal daarom ongeveer 30 m mogen bedragen;

5. De leeftijd waarop de borsthoogte wordt bereikt. Op het tijdstip 0 moet de hoogte ook 0 $\mathrm{m}$ zijn, daarna moet de groei in het eerste jaar langzaam op gang komen om vervolgens zeer snel te groeien en meestal zal $t_{130}$ in het $2^{\mathrm{e}}$ tot $4^{\mathrm{e}}$ jaar worden bereikt, maar bij hakhout en broekbos, kan dat al voor het $1^{\mathrm{e}}$ jaar zijn;

6. Het al dan significant en relevant zijn van alle parameterschattingen;

Normaliter hebben alle groeicurven een buigpunt, hier is geen verdere informatie over beschikbaar;

\subsection{Analyse}

De volgende vijf modellen zijn onderzocht.

1. Het homomorfe model van Chapman-Richards (zie Pienaar \& Turnbull, 1973):

$$
h_{\text {top }}=S \cdot\left(1-e^{-a \cdot t}\right)^{b}
$$

2. Burkhart \& Tennent (1977) paste het Chapman-Richard model aan door de parameter $a$ als functie van $S$ uit te drukken waardoor een heteromorf model ontstaat:

$$
h_{\text {top }}=S \cdot\left(1-e^{-\left(a_{0}+a_{1} \cdot S\right) \cdot t}\right)^{b}
$$

3. Jansen \& Hildebrand (1986) pasten de werkwijze van Burkhart \& Tennent toe op de $b$-parameter, hierdoor ontstaat eveneens een heteromorf model:

$$
h_{\text {top }}=S \cdot\left(1-e^{-a \cdot t}\right)^{\left(b_{0}-b_{1} \cdot S\right)}
$$


Dit model ligt ook ten grondslag aan de tabel voor zwarte els die naar Mitscherlich (1945) in de opbrengsttabellen-set van Jansen et al. (1996) is opgenomen met de parameters $a=$ $0.01739, b_{0}=1.13845$ en $b_{1}=0.01691$.

4. Jansen et al. (2016) paste dit model aan door een jeugdgroei-component toe te voegen gebaseerd op het model van Korf (1939):

$$
\begin{array}{r}
h_{\text {top }}=\left\{\begin{aligned}
f_{1}(t)=x \cdot \frac{e^{-a_{k} \cdot t^{-c}}}{e^{-a_{k} \cdot t_{x}^{c}}} & \text { for } t \leq t_{x} \\
f_{2}(t)=S_{i} \cdot\left(1-e^{-a \cdot t}\right)^{b} & \text { for } t>t_{x}
\end{aligned}\right. \\
\text { where } b=b_{0}-b_{1} \cdot S_{i} \\
t_{x}=-\frac{\ln \left(1-\left(x / S_{i}\right)^{1 / b}\right)}{a} \text { for } h_{\text {top }}=x \\
a_{k}=\frac{a \cdot b \cdot\left(S_{i} / x\right) \cdot e^{-a \cdot t_{x}} \cdot\left(1-e^{-a \cdot t_{x}}\right)^{b-1}}{c \cdot t_{x}^{-c-1}}
\end{array}
$$

Voor de grenswaarde voor de jeugdgroei gebruikten ze $x=7 \mathrm{~m}$.

5. Het Cieszewski model (2001) gebruikt een referentieleeftijd $t_{\text {ref }}$ luidt het:

$$
h_{\text {top }}=h_{\text {ref }} \cdot \frac{t^{a} \cdot\left(t_{\text {ref }}^{a} \cdot R+b\right)}{t_{\text {ref }}^{a} \cdot\left(t^{a} \cdot R+b\right)}, \text { where } R=Z+\sqrt{Z^{2}+\frac{2 \cdot b \cdot h_{\text {ref }}}{t_{\text {ref }}^{a}}} \text { and } Z=h_{\text {ref }}-c
$$

Dit heteromorfe model heeft wel een asymptoot, maar de oplossing moet gevonden worden met formule (7).

Bij vergelijking van de data in Figuur 1a en Figuur 1b blijkt dat er zeer weinig proefperken zijn met een lage boniteit, daarom zijn er met de techniek die Jansen et al. (2018b) gebruikt vier kunstmatige proefperken gemaakt met de data van de $4^{\mathrm{e}}$ Bosstatistiek. Dit zijn in wezen chronoseries met gemiddelde opperhoogte bij de leeftijden 5, 10, 15 etc. tot 60 jaar voor de kwantielen $12.5,37.5,52.5$ en $87.5 \%$.

De modellen zijn alle opgelost voor de $14+4$ "plots", en in Figuur 2 zijn per model de lijnen van de beste en slechtste boniteit getekend tezamen met de data van de $4^{\mathrm{e}}$ Bosstatistiek.

In een Multi Criteria Analyse met gelijk gewicht zijn de modellen op basis van de criteria van Paragraaf 3.1 vergeleken. Hieraan is toegevoegd het percentage punten (out\% ) wat buiten de grenzen van de minimale en maximale boniteit in Figuur 2 valt, zie Tabel 3. 


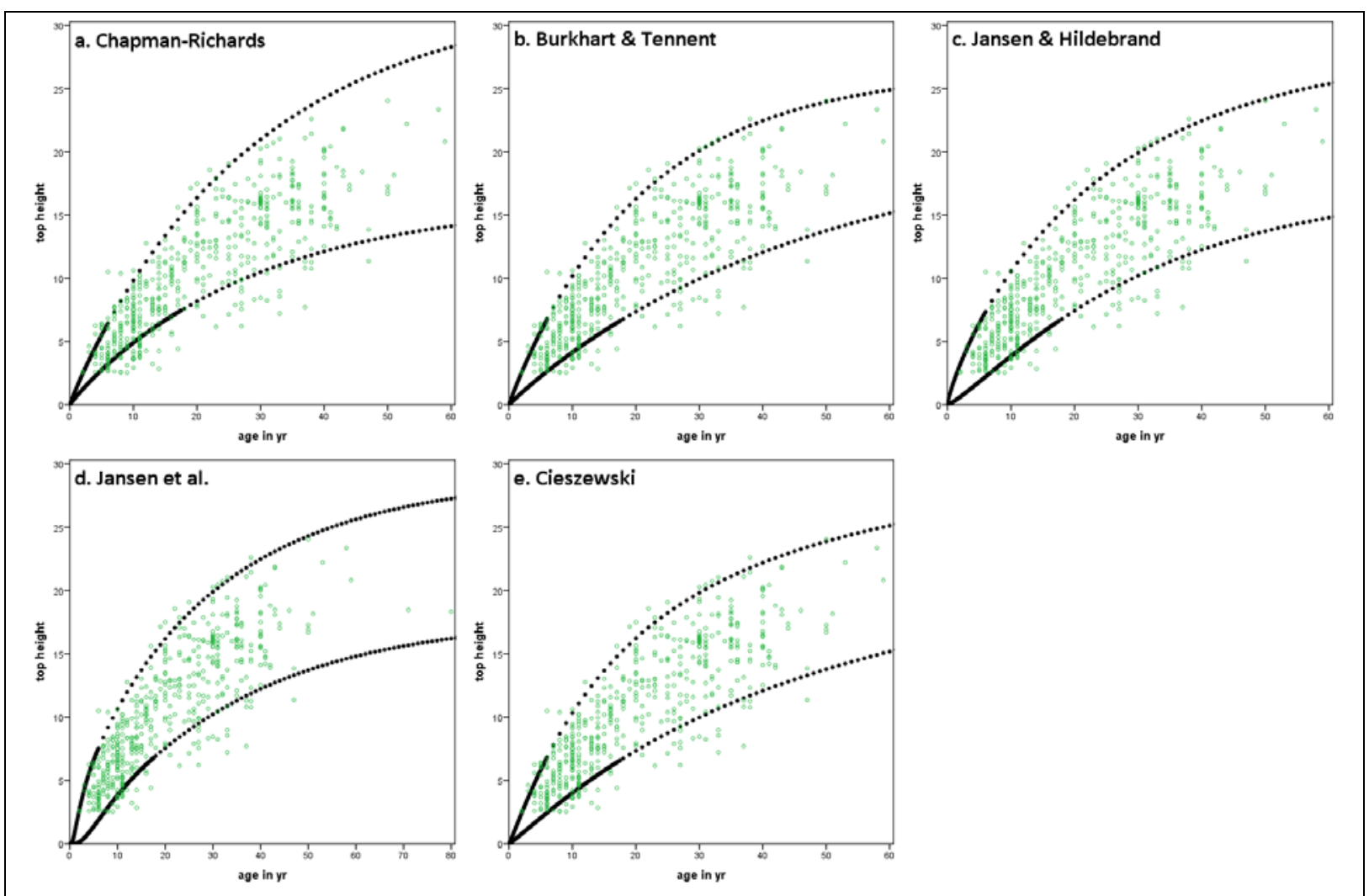

Figuur 2. Hoogtewaarnemingen in $4^{e}$ Bosstatistiek en curven van de laagste en hoogste boniteit per model.

Figure 2. Top height observations in Fourth Dutch Forest Inventory with lowest and highest site curves per model.

Tabel 3. Resultaten van niet-lineaire regressie met de geselecteerde modellen in MCA.

Table 3. Results of nonlinear regression for the selected models in MCA.

\begin{tabular}{|c|c|c|c|c|c|c|c|c|c|c|}
\hline & model & npar ${ }^{*}$ & $R^{2}$ adj & $C V$ & $h_{50}$ & $s$ & $t_{130}$ & s/ns & out\% & result \\
\hline \multirow{5}{*}{$\frac{\mathscr{\Xi}}{\frac{\mathscr{J}}{\Gamma}}$} & Chapman-Richards & 2 & 0.984 & 4.4 & $20\{13 ; 27\}$ & $25\{16 ; 33\}$ & $2\{1 ; 2\}$ & $\mathrm{s}$ & 19.7 & 5 \\
\hline & Jansen \& Hildebrand & 3 & 0.988 & 3.4 & $20\{14 ; 24\}$ & $24\{17 ; 28\}$ & $2\{1 ; 3\}$ & s & 12.4 & 1 \\
\hline & Burkhart \& Tennent & 3 & 0.988 & 3.7 & $20\{14 ; 24\}$ & $24\{21 ; 26\}$ & $1\{1 ; 2\}$ & ns & 14.1 & 4 \\
\hline & Jansen et al. & 3 & 0.988 & 4.0 & $20\{15 ; 24\}$ & $25\{18 ; 29\}$ & $2\{1 ; 4\}$ & $s$ & 12.2 & 2 \\
\hline & Cieszewski & 3 & 0.989 & 1.8 & $20\{14 ; 24\}$ & $31\{28 ; 33\}$ & $2\{1 ; 3\}$ & ns & 13.7 & 3 \\
\hline \multirow{6}{*}{ 总 } & Chapman-Richards & 2 & 5 & 5 & 5 & 4.5 & 4 & 2 & 5 & 30.5 \\
\hline & Burkhart \& Tennent & 3 & 3 & 3 & 3 & 3 & 5 & 4.5 & 4 & 25.5 \\
\hline & Jansen \& Hildebrand & 3 & 4 & 2 & 3 & 2 & 2.5 & 2 & 2 & 17.5 \\
\hline & Jansen et al. & 3 & 2 & 4 & 1 & 1 & 1 & 2 & 1 & 12 \\
\hline & Cieszewski & 3 & 1 & 1 & 3 & 4.5 & 2.5 & 4.5 & 3 & 19.5 \\
\hline & best score & & $\max$ & $\min$ & $20\{16 ; 24\}$ & $\leq 30$ & $3\{2: 4\}$ & $\mathrm{s}$ & $\min$ & \\
\hline
\end{tabular}

Hiermee is de keuze op het model van Jansen et al. (2016) gevallen. 


\subsection{Uiteindelijke model}

In formule (8) en alle volgende vergelijkingen die een onderdeel van het opbrengstmodel vormen worden de parameters genummerd als $c_{1}, c_{2}$ enzovoorts. Het model van Jansen et al. (2016) luidt:

$$
\begin{array}{r}
h_{\text {top }}=\left\{\begin{aligned}
f_{1}(t)=7 \cdot \frac{e^{-a_{k} \cdot t^{-c_{4}}}}{e^{-a_{k} \cdot t_{7}}} \quad \text { for } t \leq t_{7} \\
f_{2}(t)=S \cdot\left(1-e^{-c_{1} \cdot t}\right)^{b} \quad \text { for } t>t_{7}
\end{aligned}\right. \\
\text { where } b=c_{2}-c_{3} \cdot S \\
t_{7}=-\frac{\ln \left(1-(7 / S)^{1 / b}\right)}{c_{1}} \\
a_{k}=\frac{c_{1} \cdot b \cdot(S / 7) \cdot e^{-c_{1} \cdot t_{x}} \cdot\left(1-e^{-c_{1} \cdot t_{7}}\right)^{b-1}}{c_{4} \cdot t_{7}^{-c_{4}-1}}
\end{array}
$$

Met een $R^{2}$ adj van 0.988 werden de parameters van Tabel 4 gevonden.

Tabel 4. Parameters voor hoogteontwikkeling met Model (8).

Table 4. Parameters for height development with Model (8).

\begin{tabular}{|l|rrrr|}
\hline & \multicolumn{3}{c}{ 95\% Confidence Interval } \\
Parameter & Estimate & \multicolumn{1}{c|}{ Std. Error } & Lower Bound & Upper Bound \\
\hline$c_{1}$ & 0.0312 & 0.004 & 0.024 & 0.039 \\
$c_{2}$ & 1.6809 & 0.268 & 1.148 & 2.214 \\
$c_{3}$ & 0.0315 & 0.010 & 0.011 & 0.052 \\
$c_{4}$ & 0.6086 & 0.218 & 0.175 & 1.042 \\
\hline
\end{tabular}

In Figuur 3 is de met Formule (8) voorspelde opperhoogte uitgezet tegen de gemeten opperhoogte voor alleen de permante proefperken. De gearceerde rode lijn betreft de lineaire fit, te zien is dat hoge waarden van de opperhoogte iets worden onderschat en lage waarden iets overschat. Maar dat gaat maximaal om $30 \mathrm{~cm}$, is niet significant en dus verwaarloosbaar. 


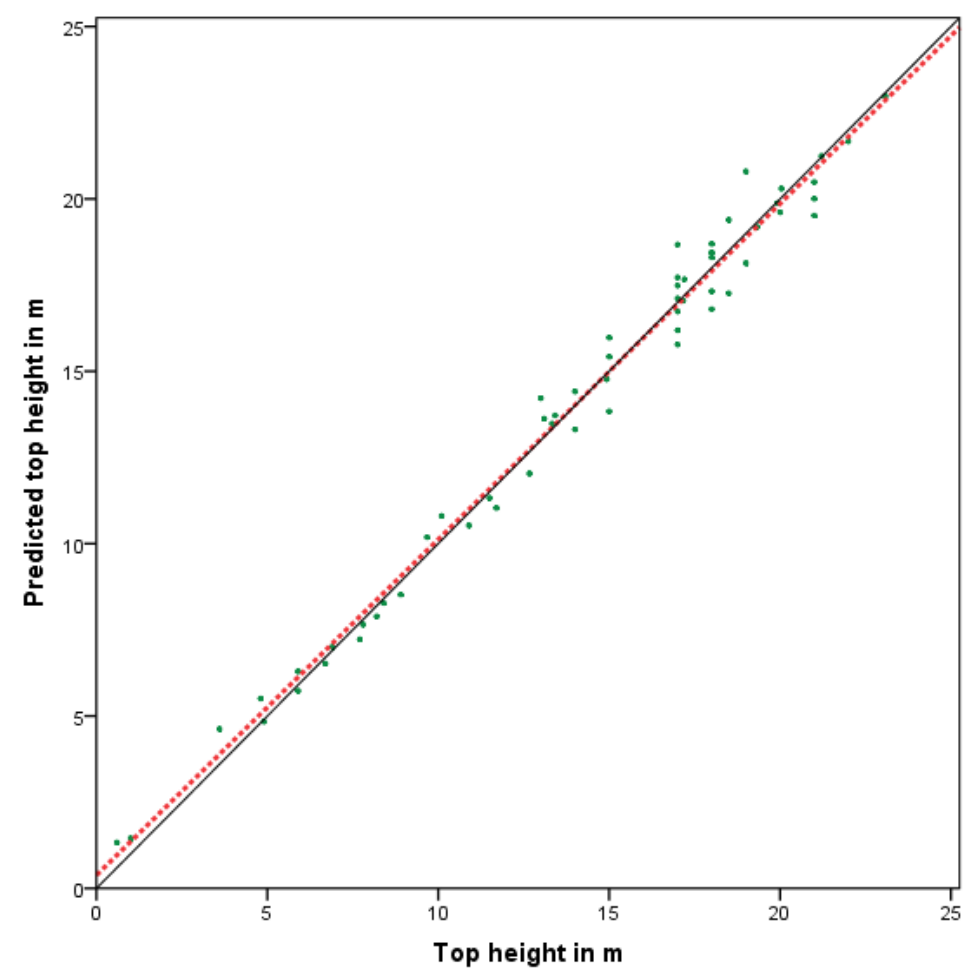

Figuur 3. Voorspelde opperhoogte met Formule (8) in relatie met gemeten opperhoogte op tijdstip van de waarneming. De rode lijn geeft de lineaire fit weer, de zwarte lijn geeft de perfecte fit met een hoek van $45^{\circ}$ weer.

Figure 3. Predicted top height with model (8) in relation with observed top height. The red line represents the linear fit, the black line the perfect fit with an angle of $45^{\circ}$.

\subsubsection{Analyse van de residuen bij de permanente plots}

In Figuur 4 zijn de residuen van model (8) van de permanente plots uitgezet tegen de systeemvariabele leeftijd en de afgeleide systeemvariabele $h_{50}$. De lichte onzuiverheid ten aanzien van de leeftijd is niet significant, en er zijn geen uitbijters aanwezig. Ook de residuen ten opzichte van de opperhoogte (hier niet getekend) bleken ondanks de geringe afwijking in Figuur 3 niet significant.
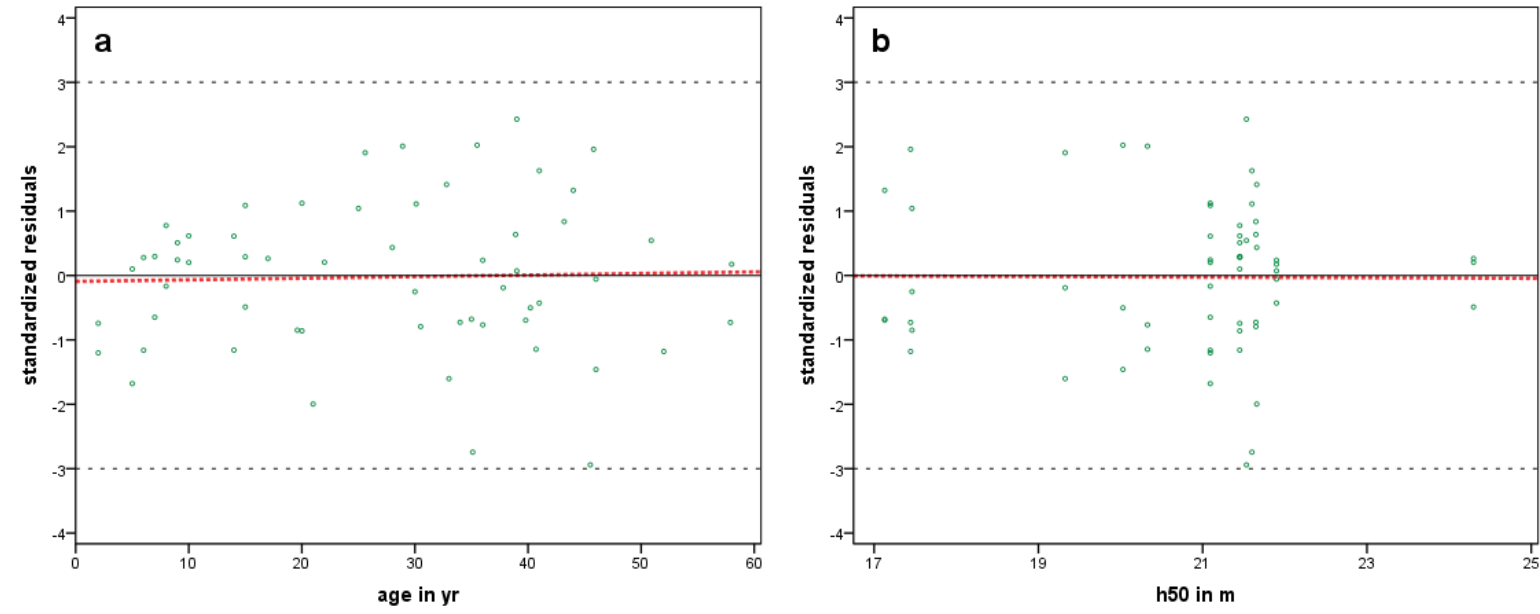

Figuur 4. Gestandaardiseerde residuen in relatie tot leeftijd (a) en $h_{50}(b)$, de rode lijn geeft de lineaire fit weer.

Figure 4. Standardized residuals in relation to top height (a) and $h_{50}(b)$, the red line is the linear fit. 


\subsubsection{Boniteitindeling}

Met de gegevens van de $4^{\mathrm{e}}$ bosstatistiek (CBS, 1985) is van 518 monocultures met zwarte els de $h_{50}$ bepaald volgens de methode van Jansen et al. (2016). Dit leidt tot de verdeling over de $h_{50}$ zoals weergegeven in Figuur 5.

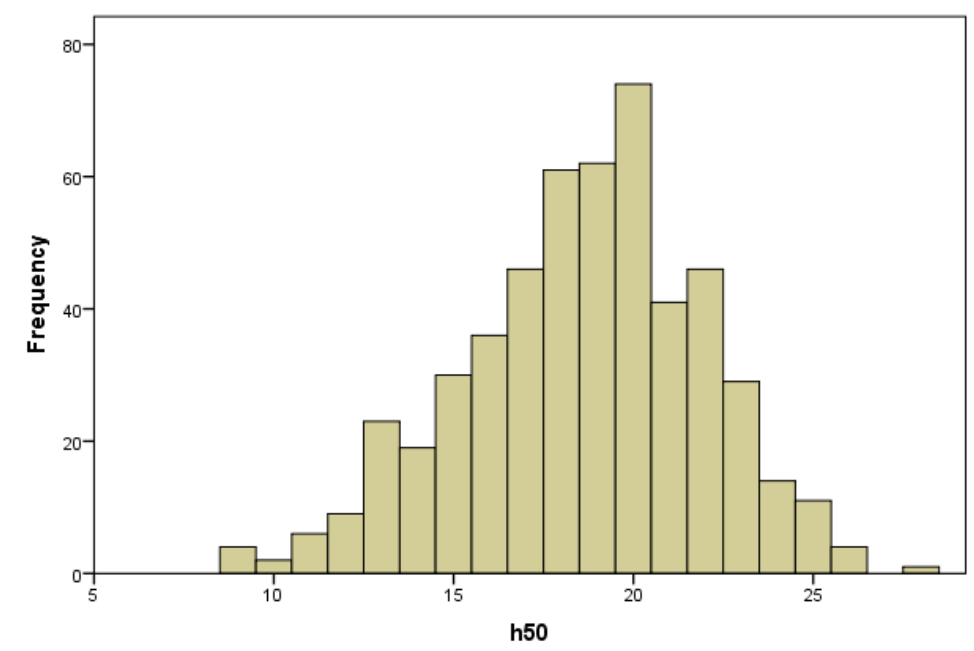

Figuur 5. Frequentiehistogram van $h_{50}$ in $4 e$ bosstatistiek.

Figure 5. Frequency histogram of $h_{50}$ per forest region in the Fourth Dutch Forest Inventory.

Het frequentiehistogram van Figuur 5 is heeft een links scheve verdeling. Er is gekozen om het deel tussen 10.5 en $25.5 \mathrm{~m}$ in 5 boniteiten in te delen. Zie Tabel 5 voor het resultaat. Met deze indeling heeft $1.0 \%$ van alle opstanden van de zwarte els een betere boniteit dan de $\mathrm{I}^{\mathrm{e}}$ en $1.2 \%$ heeft een slechtere boniteit dan de $V^{e}$.

De beste boniteiten blijken oververtegenwoordigd in de dataset.

Tabel 5. Indeling in boniteiten gebaseerd op de $\boldsymbol{h}_{50}$.

Table 5. Classification in site classes based on the $h_{50}$.

\begin{tabular}{|c|c|c|c|c|}
\hline $\begin{array}{c}\text { Boniteit } \\
\text { site class }\end{array}$ & $\begin{array}{c}\boldsymbol{h}_{\mathbf{5 0}} \\
\boldsymbol{h}_{50}\end{array}$ & $\begin{array}{c}\text { Bereik } \boldsymbol{h}_{\mathbf{5 0}} \\
\text { range } h_{50}\end{array}$ & $\begin{array}{c}\text { \% in dataset } \\
\text { \% in data set }\end{array}$ & $\begin{array}{c}\text { \% in 4 } \\
\text { \% in 4th forest inventory }\end{array}$ \\
\hline$<$ I & & $>25.5$ & & 1.0 \\
I & 24.0 & $(22.5-25.5)$ & 5.1 & 10.4 \\
II & 21.0 & $(19.5-22.5)$ & 74.6 & 31.1 \\
III & 18.0 & $(16.5-19.5)$ & 20.3 & 32.6 \\
IV & 15.0 & $(13.5-16.5)$ & & 16.4 \\
V & 12.0 & $(10.5-13.5)$ & & 7.3 \\
$>$ V & & $<10.5$ & & 1.2 \\
\hline
\end{tabular}

De verdeling over de leeftijdsklassen binnen de boniteiten is homogeen, zie Tabel 6 
Tabel 6. Aantal opstanden per leeftijdsklassen en boniteit in $4^{\mathrm{e}}$ Bosstatistiek.

Table 6. Age classes per site class in Fourth National Forest Inventory (number of stands).

\begin{tabular}{|c|rrrrr|r|}
\hline leeftijdsklasse & $\mathbf{S}$ & II & III & IV & I V & totaal \\
\hline$<10$ & 21 & 43 & 52 & 13 & 10 & 139 \\
$10-20$ & 16 & 43 & 44 & 31 & 13 & 147 \\
$20-30$ & 12 & 41 & 27 & 17 & 11 & 108 \\
$30-40$ & 7 & 28 & 37 & 16 & 9 & 97 \\
$40-50$ & 3 & 3 & 8 & 6 & 1 & 21 \\
$50-60$ & & 3 & 1 & & & 4 \\
$>60$ & & & & 2 & & 2 \\
\hline Totaal & 59 & 161 & 169 & 85 & 44 & 518 \\
\hline
\end{tabular}

In Figuur 6 is de hoogteontwikkeling per boniteit samen met die van de proefperken en met die van de gegevens van de $4^{\mathrm{e}}$ Bosstatistiek weergegeven, ter vergelijking zijn de twee waarnemingen tussen 60 en 80 jaar in Figuur 6b weggelaten.
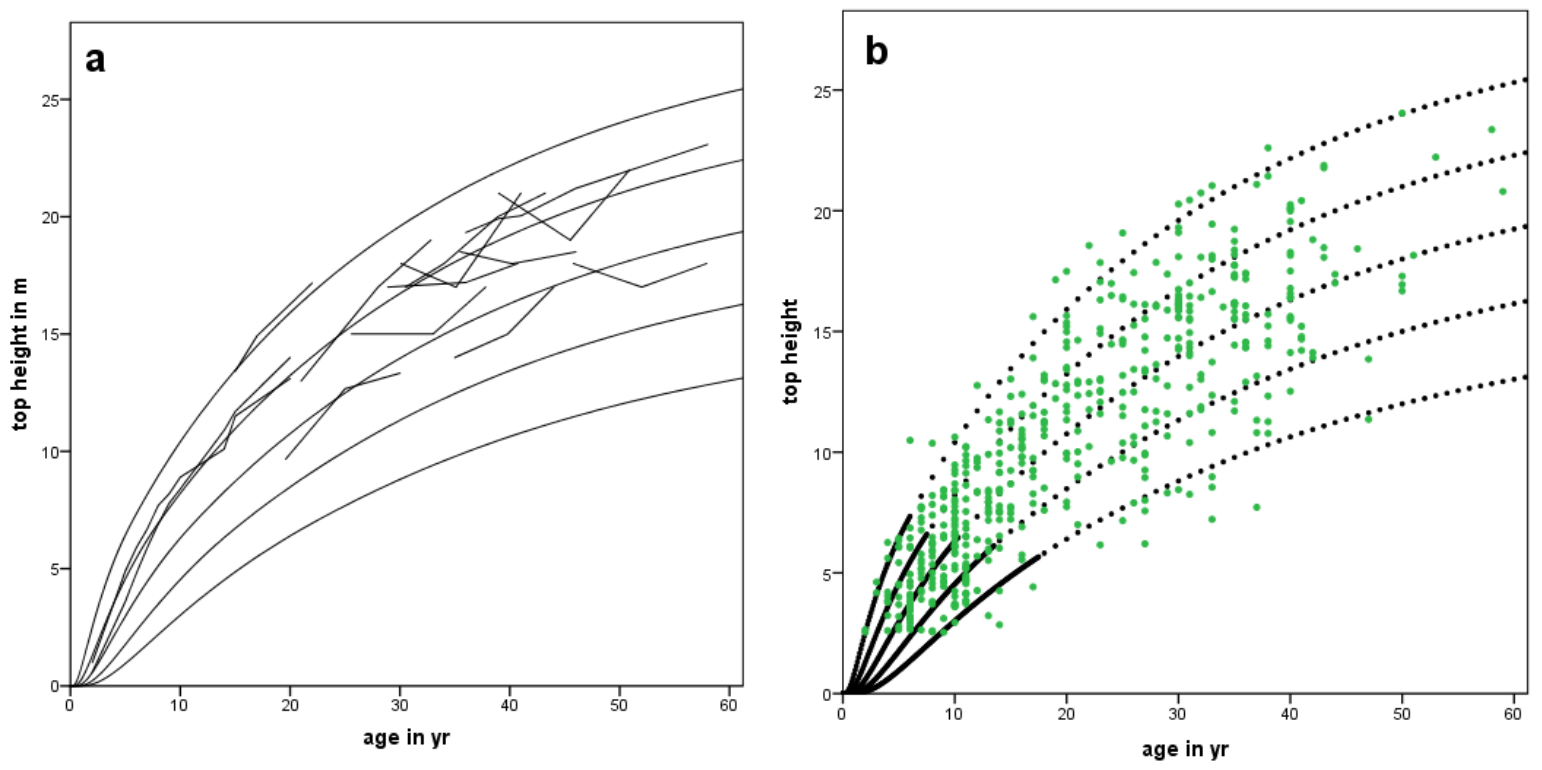

Figuur 6. Boniteitcurven voor de zwarte els in Nederland met de hoogteontwikkeling van de proefperken(a) en met de waarnemingen van de $4^{e}$ Bosstatistiek (b).

Figure 6. Top height development with site curves for black alder at experimental plots (a) and at data Fourth National Forest inventory (b).

\subsection{Conclusie}

De hoogtegroei van de zwarte els is onderzocht en het model van Jansen et al. (2016) is gekozen. Hiermee is een indeling in 5 boniteiten gemaakt. Ongeveer $1 \%$ van de zwarte elzenbossen in Nederland heeft een betere boniteit dan de hier gepresenteerde boniteit I en ruim $1 \%$ heeft een lagere boniteit dan boniteit V. 


\section{Opbrengstniveau}

Naast de hoogtegroei vindt ook diktegroei plaats. Dit resulteert in diameterbijgroei $i_{d}=\left(d_{2}-d_{1}\right) /\left(t_{2}-t_{1}\right)$ en grondvlakbijgroei $i_{G}=\left(G_{2}-G_{1}\right) /\left(t_{2}-t_{1}\right)$. Hoogtegroei en diktegroei samen resulteren in een volumebijgroei. In opbrengsttabellen is een belangrijk doel juist de volumebijgroei te bepalen. Aangezien het boomvolume in de dataset een afgeleide, berekende variabele is en niet berust op een primaire waarneming, zal ook de volumebijgroei indirect worden berekend. Diameter en het totale grondvlak zullen in de loop van de tijd toenemen, maar gelijktijdig neemt ook de hoogte toe.

Jansen et al. (2016) onderzochten voor douglas een aantal groeimodellen. Ze vonden dat tot een opperhoogte van $7 \mathrm{~m}$ de opstandontwikkeling het best kan worden verklaard met een voorspelling van de diameter voor dunning. Vanaf een opperhoogte $7 \mathrm{~m}$ werd de opstandontwikkeling beter verklaard door de grondvlakbijgroei. In Paragraaf 4.1 zal de diameterontwikkeling en daaraan gekoppeld de grondvlakontwikkeling worden geanalyseerd en gemodelleerd. In Paragraaf 4.2 zal de grondvlakbijgroei vanaf een hoogte van $7 \mathrm{~m}$ worden geanalyseerd en gemodelleerd.

\subsection{Diameter- en grondvlakontwikkeling tot een hoogte van $7 \mathrm{~m}$}

Als maat voor de diameter is gekozen voor de "gemiddelde" diameter van de opstand voor dunning $\left(d_{b t}\right)$. Onder "gemiddelde" wordt hier verstaan het kwadratische gemiddelde. Het gaat dus om de $d_{g}$, maar de toevoeging $g$ (van gemiddeld grondvlak) is weggelaten.

De in vorige studies gebruikte modellen kunnen niet gebruikt worden bij gebrek aan data. In Figuur 7 zijn de data van opstanden met een hoogte tot $7.5 \mathrm{~m}$ uit de $4^{\mathrm{e}}$ Bosstatistiek (CBS, 1985) weergegeven, met de beste fittende powerfunctie.

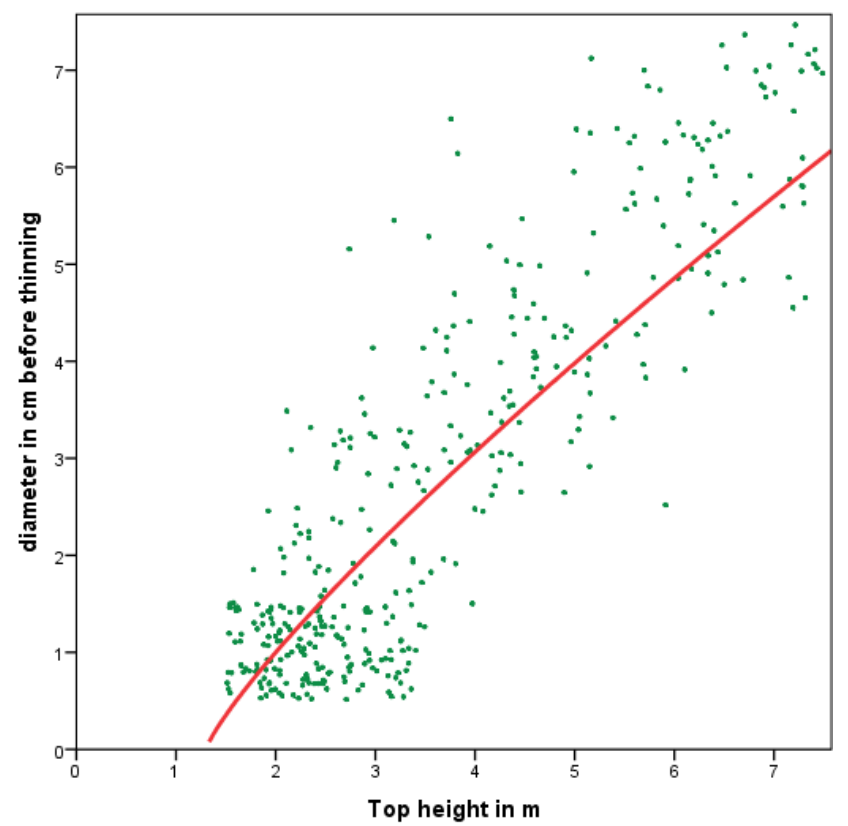

Figuur 7. Diameter en hoogte bij data $4^{e}$ Bosstatistiek met in rood de beste fit met een powerfunctie.

Figure 7. Diameter and height at data Fourth Dutch Forest Inventory. The red line represents the best fit with a power function. 
In de vorige modellen kon een formules voor $d_{7}$ worden ontwikkeld op basis van beginstamtal of de gemiddelde boomafstand, maar in data van de $4^{\mathrm{e}}$ Bosstatistiek zijn die gegevens niet beschikbaar en is $d_{7}$ een te schatten parameter.

Voor de ontwikkeling tot een hoogte van $7 \mathrm{~m}$ is het volgende model gebruikt:

$$
g=\pi \cdot\left(\frac{d}{200}\right)^{2}=\pi \cdot\left(\frac{d_{7}}{200}\right)^{2} \cdot\left\{\left(\frac{h-1.30}{7-1.30}\right)^{c_{5}}\right\}^{2} \text { for } h_{\text {top }} \leq 7 \mathrm{~m} \quad \text { where } d_{7}=c_{6}
$$

Met $R^{2}$ adj $=0.806$ is model (9) opgelost met de parameterschattingen van Tabel 7 Bij gebruik in het model voor de te maken opbrengsttabel worden in model (9) $d$ en $h$ vervangen door $d_{b t}$ en $h_{\text {top }}$.

Tabel 7. Parameters voor Model (9)

Table 7. Parameter estimation with Model (9).

\begin{tabular}{|l|r|r|r|r|}
\hline & & & \multicolumn{2}{|c|}{$95 \%$ Confidence Interval } \\
\cline { 4 - 5 } Parameter & Estimate & Std. Error & Lower Bound & \multicolumn{1}{c|}{ Upper Bound } \\
\hline$c_{5}$ & 0.8440 & 0.034 & 0.778 & 0.910 \\
$c_{6}$ & 6.5083 & 0.074 & 6.363 & 6.653 \\
\hline
\end{tabular}

Bij de regressiediagnose werden geen punten van aandacht gevonden.

Conclusie

Met de gegevens van de $4^{\mathrm{e}}$ Bosstatistiek is model (9) opgelost.

\subsection{Grondvlakbijgroei}

Bij de analyse van de grondvlakbijgroei is als grens is een opperhoogte van $7 \mathrm{~m}$ aangehouden, ontwikkeling van het grondvlak tot die hoogte is in Paragraaf 4.1 al besproken. Hier wordt de groei vanaf een opperhoogte van $7 \mathrm{~m}$ behandeld.

De grondvlakbijgroei betreft een berekende waarneming tussen 2 opnamen, de leeftijd en opperhoogte betreffen dan het gemiddelde tussen beide opnamen.

Totaal zijn er 27 opnamen beschikbaar voor de analyse. 

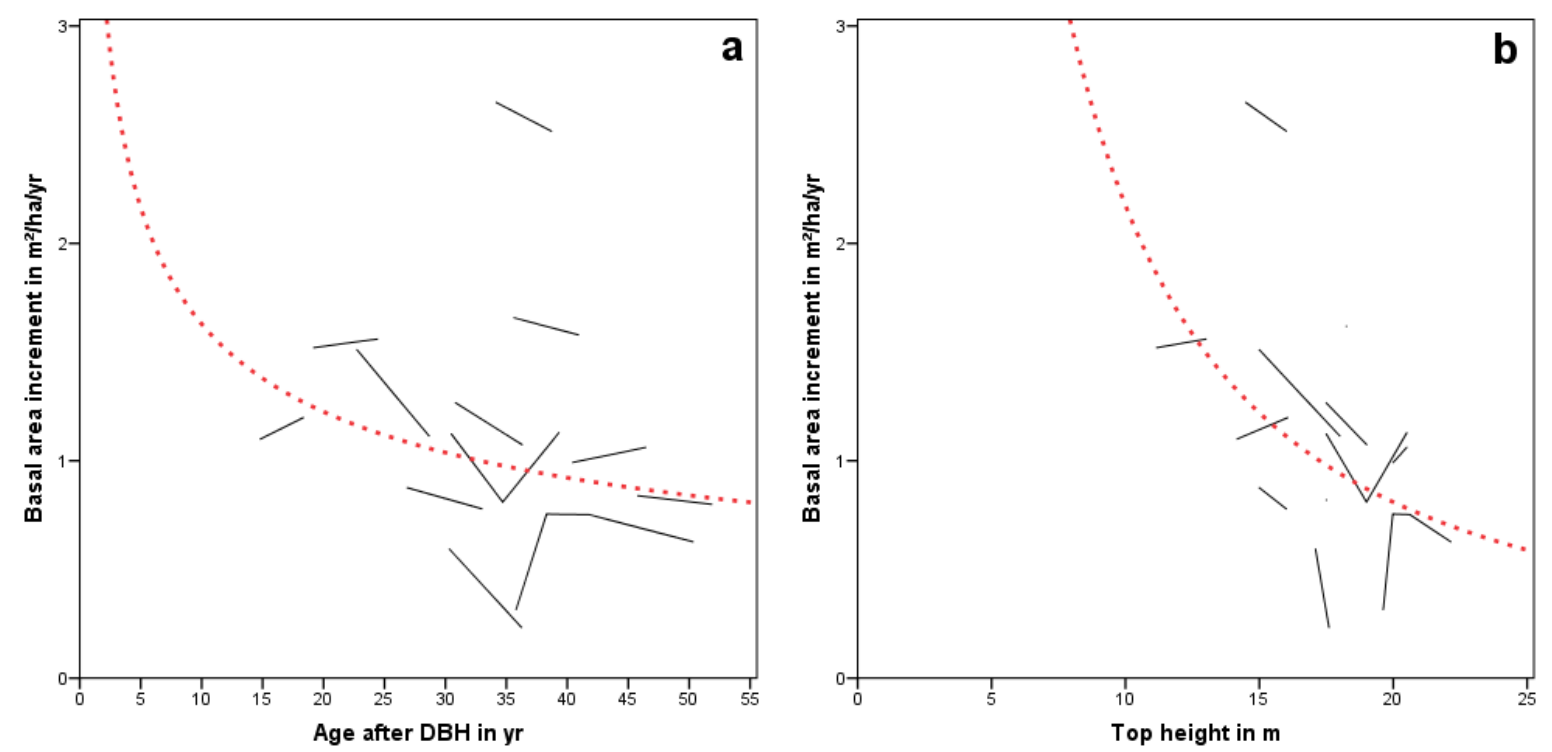

Figuur 8. Grondvlakbijgroei als functie van de leeftijd (a) en opperhoogte (b). De zwarte lijnen geven het verloop binnen één plot aan, de rode lijn de beste fit voor een power-functie over alle opnamen.

Figure 8. The basal area increment as a function of age (a) and top height (b). The black line represents the course within a plot, the red lines represents the best fit with a power function for all recordings.

Jansen et al. (2016) ontwikkelden voor de grondvlakbijgroei van douglas het volgende model:

$$
i_{G, j k}=Y l_{j} \cdot P L_{k} \cdot f_{1}(S \%) \cdot f_{2}\left(h_{\text {ref }}\right) \cdot\left\{\frac{F_{3}\left(h_{2}, t_{2}\right)-F_{3}\left(h_{1}, t_{1}\right)}{\Delta t}\right\}
$$

where $Y I=$ year index and $P L=$ plot level

Voor de douglas bleek $f_{2}$ geen significante bijdrage te leveren.

Hierin is $F_{3}$ een power-functie. In de Figuren 8 a en $8 \mathrm{~b}$ zijn de afgeleiden van $F_{3}$ naar $t$ en $h_{\text {top }}$, in beide gevallen dus weer een powerfunctie, getekend. Op grond daarvan mag geconstateerd worden dat een powermodel zoals Jansen et al. (2016) gebruiken geschikt is om de grondvlakbijgroei te verklaren. Het uitgewerkte model zonder jaarindex $Y I$ of de correctiefactoren $c f_{80}$ voor de periode voor en na 1980 en zonder plotniveau luidt: 


$$
\begin{aligned}
& i_{G}=\operatorname{cor}_{5 \%} \cdot c_{8} \cdot\left\{c_{12} \cdot \operatorname{Term}_{h} / d t+\left(1-c_{12}\right) \cdot \operatorname{Term}_{t} / d t\right\} \\
& \text { where } \operatorname{Term}_{h}=\left(h_{2 c}-1.30\right)^{c_{11}}-\left(h_{1}-1.30\right)^{c_{11}} \text { and } \operatorname{Term}_{t}=\left(t_{2}-t_{130}\right)^{c_{11}}-\left(t_{1}-t_{130}\right)^{c_{11}} \\
& t_{1}=t_{i, j} \text { and } t_{2}=t_{i, j+1} \text { for the } j^{\text {th }} \text { record in the } i^{\text {th }} \text { plot } \\
& h_{2 c}= \begin{cases}h_{2} & \text { for } h_{2}>h_{1} \\
h_{1}+\hat{h}_{2}-\hat{h}_{1} & \text { for } h_{2} \leq h_{1}\end{cases} \\
& h_{1} \text { and } h_{2} \text { are the top heights at time } t_{1} \text { and } t_{2} \\
& \operatorname{cor}_{S \%}= \begin{cases}1 & \text { for } S \%_{0} \leq c_{10} \\
1-c_{9} \cdot \sqrt{S \%_{0}-c_{10}} & \text { for } S \%_{0}>c_{10}\end{cases} \\
& S \%_{0}=\text { Hart-Becking spacing index after thinning at time } t_{1}
\end{aligned}
$$

In eerste instantie werd er met $R^{2}$ adj $=0.097$ en standaarddeviatie $0.53 \mathrm{~m}^{2} \mathrm{jr}^{-1} \mathrm{ha}^{-1}$ een oplossing gevonden, in een daarna uitgevoerde regressiediagnose werd gevonden dat plotnummer 7 en 8 grotendeels verantwoordelijk waren voor het magere resultaat, een verklaring ervoor werd niet gevonden. De twee proefperken zijn daarna uitgesloten van de analyse. Daarna werden met 23 waarnemingen, $R^{2} \mathrm{adj}=0.457$ en standaarddeviatie $0.26 \mathrm{~m}^{2} \mathrm{jr}^{-1} \mathrm{ha}^{-1}$ werden de parameters van Tabel 8 gevonden. Voor de zwarte els speelt $f_{2}$ net als bij de douglas geen rol. De factor Term $_{h}$ in Formule (11) bleek geen bijdrage te leveren. Door de hoge onderlinge negatieve correlatiecoëfficiënt $(-0.997)$ tussen $c_{8}$ en $c_{11}$ zijn niet beide parameters significant.

Tabel 8. Parameterschatting met Model (11).

Table 8. Parameter estimation with Model (11).

\begin{tabular}{|l|rrrr|}
\hline & \multicolumn{3}{c}{ 95\% Confidence Interval } \\
Parameter & \multicolumn{1}{|c}{ Estimate } & Std. Error & Lower Bound & Upper Bound \\
\hline$c_{8}$ & 8.4270 & 7.968 & -8.251 & 25.105 \\
$c_{9}$ & 0.1552 & 0.031 & 0.091 & 0.219 \\
$c_{10}$ & 15.6656 & 1.368 & 12.802 & 18.529 \\
$c_{11}$ & 0.6001 & 0.179 & 0.226 & 0.974 \\
$c_{12}$ & 0 & & & \\
\hline
\end{tabular}




\section{Dunningsysteem}

In de dunningproeven van studie 1 en 2 zijn verschillende vaste dunninggraden nagestreefd (zie Tabel 9).

Tabel 9. Dunninggraden

Table 9. Thinning grades

\begin{tabular}{|c|c|l|}
\hline Tgr $\mathbf{0}$ & S\% bij $\mathbf{5 0}$ jr & Omschrijving \\
\hline 1 & 13 & zonder dunning \\
2 & 16 & zwakke laagdunning \\
3 & 19 & matige laagdunning \\
4 & 22 & sterke laagdunning \\
5 & 25 & zeer sterke laagdunning \\
6 & 28 & open stand \\
\hline
\end{tabular}

Er is reden om aan te nemen dat de dunninggraad, zoals hier gedefinieerd via het $S \%$, op latere leeftijd moet stijgen omdat de vorm wijzigt zodra topsterfte optreedt.

Het model luidt dan:

$$
S \%= \begin{cases}13+3 \cdot\left(\operatorname{Tgr}_{0}-1\right) & \text { age } \leq 50 \\ 13+3 \cdot\left(\operatorname{Tgr}_{0}-1\right)+c_{13} \cdot(\text { age }-50) & \text { age }>50\end{cases}
$$

Vanaf de eerste dunning of sterfte tot een leeftijd van 50 jaar komt het $S \%$, behorend bij de in te stellen dunninggraad $T g r_{0}$, overeen met die uit de tweede kolom van de tabel, daarna loopt het $S \%$ langzaam op.

Een model om $c_{13}$ te schatten luidt:

$$
S \%_{i j}=\left\{\begin{array}{ll}
S \%_{j} & \text { age } \leq 50 \text { and } h_{\text {top }}>7 \\
S \%_{j}+c_{13} \cdot\left(a g e_{i j}-50\right) & \text { age }>50 \text { and } h_{\text {top }}>7
\end{array} \text { for the } i^{\text {th }} \text { record in the } j^{\text {th }}\right. \text { plot }
$$

Met 39 waarnemingen en $R^{2}$ adj $=0.932$ bleek $c_{13}=0.0588$ maar deze waarde was niet significant. In drie vergeleken opbrengsttabellen (zie tabel 10) werd een gemiddelde waarde van $c_{13}=0.0661$ gevonden, deze waarde is gebruikt. De dunninggraden hebben dus niet langer een vast maar een variabel $S \%$.

Tabel 10. Verloop $S \%$ in vergeleken opbrengsttabellen vanaf 50 jaar.

Table $10 . \quad$ Course of $S \%$ in compared yield tables from 50 year and up.

\begin{tabular}{|llrr|}
\hline Tabel & land & S\% bij 50\% & $\mathbf{\Delta ~ S \% ~ / j r ~}$ \\
\hline Mitscherlich 1945 & Duitsland & 24.1 & 0.1382 \\
Lockow $^{*}{ }^{\prime}, 1993$ & Duitsland & 20.5 & 0.0133 \\
Sopp $^{*}, 1974$ & Hongarije & 20.5 & 0.0468 \\
\hline
\end{tabular}

${ }^{*}$ in: Claessens et al., 2010 
Jansen et al. (2016) voorspellen de diameter na dunning met een modificatie van het model van La Bastide \& Faber (1972):

$$
\begin{aligned}
d_{a t}= & d_{b t} \cdot\left\{R \cdot \frac{a_{a t}}{a_{b t}}+1-R\right\} \\
& \text { where } R=c_{14}+c_{15} \cdot h_{50}+c_{16} \cdot \sqrt{T g r}+c_{17} \cdot t
\end{aligned}
$$

Bij de analyse zijn alle opnamen uitgesloten waarbij er minder dan 4 bomen uit het proefperk waren verdwenen, omdat dit meestal geen dunning maar sterfte betreft. Ook opnamen waarbij de diameter voor dunning hoger was dan die na dunning zijn uitgesloten, omdat dit geen normale laagdunning betreft. Door die selectie zijn er maar 8 waarnemingen beschikbaar en bleek model (14) niet schatbaar.

Daarom is het originele model van La Bastide \& Faber gefit:

$$
d_{a t}=d_{b t} \cdot\left\{c_{18} \cdot \frac{a_{a t}}{a_{b t}}+1-c_{18}\right\}
$$

Met een $R^{2}$ adj van 0.995 werd voor de parameter gevonden $c_{18}=0.2818$ in een $95 \%$ betrouwbaarheidsinterval $\{0.096 ; 0.467\}$. 


\section{Constructie Opbrengsttabellen}

Met de in deze studie gevonden relaties zullen nu nieuwe opbrengsttabellen worden gemaakt met verschillende dunninggraden.

Al eerder is besloten een indeling in relatieve boniteiten te maken, met daaraan gekoppeld de "hoogte" op 50 jaar. Er is gekozen voor de volgende presentatie van gegevens op dezelfde wijze als voor de douglas door Jansen et al. (2016). Er zijn echter geen data beschikbaar om de dominante hoogte en dominante diameter te bepalen, dus deze gegevens komen niet meer voor in deze opbrengsttabellen.

Voor een groot aantal van deze gegevens kunnen de gevonden relaties in de voorafgaande hoofdstukken worden gebruikt. Maar er zullen nog wat allometrische relaties gefit moeten worden, voor variabelen die tot nu toe nog niet voorkwamen.

\subsection{Overige allometrische relaties}

\section{Gemiddelde opstandhoogte}

Jansen et al. (2016) vonden voor de gemiddelde hoogte $\left(h_{g}\right)$ na dunning een powerfunctie gevonden met in de loop van de ontwikkeling wijzigende parameters:

$$
\begin{aligned}
& h_{a t}= \begin{cases}h_{a t(2)} & \text { for } h_{\text {top }} \leq 1.30 \mathrm{~m} \\
h_{a t(2)} & \text { for } h_{a t(1)} \leq h_{a t(2)} \\
h_{a t(1)} & \text { else }\end{cases} \\
& \text { where } h_{a t(1)}=\left(c_{19}+c_{20} \cdot a g e\right) \cdot h_{t o p}^{\left(c_{21}-c_{22} \cdot h_{\text {top }}\right)} \\
& \quad h_{a t(2)}=c_{23} \cdot h_{\text {top }} \text { and } c_{23}=0.8 \text { (a set value) }
\end{aligned}
$$

Met een $R^{2}$ adj van 0.973 werden de volgende parameters gevonden: $c_{19}=0.6605, c_{20}=0$, $c_{21}=1.1158$ en $c_{22}=0$. De begrenzing met de $c_{23}$ parameter is achteraf ingesteld omdat de basisformule voor lage leeftijden onrealistische waarden opleverde.

Voor de hoogte voor dunning volgde:

$$
h_{b t}=c_{24} \cdot h_{a t} \quad \text { with } R^{2} \text { adj }=0.995 \text { and } c_{24}=0.9929
$$

\section{Opstandvolume}

In de data zijn de boomvolumes bepaald met de Formule (18) voor zwarte els zijn de constanten van Schoonderwoerd et al. (1991) zijn gebruikt. Ze gebruikten het Schumacher-Hallmodel (1933):

$$
v=d^{c_{25}} \cdot h^{c_{26}} \cdot e^{c_{27}} \text { met } d \text { in } \mathrm{cm}, h \text { in } \mathrm{m} \text { en } v \text { in } \mathrm{dm}^{3}
$$

Voor zwarte els geldt: $c_{25}=1.90193, c_{26}=0.84488$ en $c_{27}=-2.55070$. 
Formule (18) is niet geschikt om het opstandvolume te bepalen. In het verleden werd gebruik gemaakt van de gemodificeerde opstandvolumefunctie van Heisterkamp (1981), de functie luidt:

$$
\begin{aligned}
V= & c_{28} \cdot G^{c_{29}} \cdot h_{\text {top }}^{\left(c_{30}+c_{31} \cdot t_{0}\right)} \text { with } G \text { in } \mathrm{m}^{2} / \mathrm{ha}, h_{\text {top }} \text { in } \mathrm{m} \text { and } V \text { in } \mathrm{m}^{3} / \text { ha } \\
& \text { where } t_{0}=t-t_{1.30}
\end{aligned}
$$

Met een $R^{2}$ adj van 0.984 werden de volgende parameters gevonden: $c_{28}=0.9115, c_{29}=$ $1.0050, c_{30}=0.7388$ en $c_{31}=0$ (niet significant) .

De formule van Heisterkamp is ontwikkeld voor opbrengsttabellen die een startwaarde hadden voor de opperhoogte, voor zwarte els was die $7 \mathrm{~m}$. Daar beneden moet met de Formule (18) worden gewerkt.

\section{Beginstamtal}

Als beginstamtal is gekozen voor $5000\left(=c_{32}\right)$.

\section{Grenswaarde}

De steeds terugkerende grenswaarde voor de opperhoogte van $7 \mathrm{~m}$ is de parameter $c_{33}$ in de modellen. En geeft daarbij de boven grens aan voor de jeugdgroei.

\subsection{Opbrengsttabellen}

Allereerst is gekozen welke tabellen gepubliceerd zullen worden. Er is gekozen voor een opbrengsttabel voor Nederland met één dunninggraad en vijf boniteiten.

In Tabel 6 is de verdeling over boniteiten en leeftijdsklassen gegeven voor het aantal opstanden in de $4^{\mathrm{e}}$ Bosstatistiek met een hoogte vanaf $3 \mathrm{~m}$ in Nederland. Dit geeft de behoefte aan tabellen weer, terwijl Tabel 11 een indicatie van de mogelijkheden geeft.

Tabel 11. Leeftijdsinterval in dataset per dunninggraad en boniteit.

\begin{tabular}{|c|c|c|c|c|c|}
\hline & \multicolumn{5}{|c|}{ leeftijdsinterval per boniteit } \\
\hline Dunninggraad & $\mathbf{I}$ & II & III & IV & $\mathbf{V}$ \\
\hline zonder dunning & & $30-51$ & $35-58$ & & \\
\hline zwakke laagdunning & $15-22$ & $31-46$ & & & \\
\hline matige laagdunning & & $21-33$ & & & \\
\hline sterke laagdunning & & $26-28$ & $12-23$ & & \\
\hline zeer sterke laagdunning & & $29-58$ & & & \\
\hline open stand & & & $20-30$ & & \\
\hline
\end{tabular}

Table 11. Age interval in the data set by thinning grade and site class.

Extrapolatie buiten het waarnemingsmateriaal moet in principe beperkt worden maar is onvermijdelijk (zie Tabel 11). De maximale leeftijd is op 60 jaar gesteld. 
Als dunninggraad is voor zwarte els gekozen voor een matige laagdunning.

Jansen et al. (2016) geven voor de douglas hoe deze geconstrueerd wordt. Deze werkwijze is gevolgd, uiteraard met aanpassing voor afwijkende onderdelen.

In Tabel 12 is een lijst met de geschatte parameters opgenomen.

Tabel 12. Lijst met alle parameters.

Table 12. List with all parameters.

\begin{tabular}{|l|cr|}
\hline Parameter & Formula number & Value \\
\hline$c_{1}$ & $(8)$ & 0.0311964 \\
$c_{2}$ & $(8)$ & 1.6808743 \\
$c_{3}$ & $(8)$ & 0.0315163 \\
$c_{4}$ & $(8)$ & 0.6086381 \\
$c_{5}$ & $(9)$ & 0.8440306 \\
$c_{6}$ & $(9)$ & 6.5082786 \\
$c_{7}$ & not for black alder & \\
$c_{8}$ & $(11)$ & 8.4270304 \\
$c_{9}$ & $(11)$ & 0.1552461 \\
$c_{10}$ & $(11)$ & 15.6655711 \\
$c_{11}$ & $(11)$ & 0.6000504 \\
$c_{12}$ & $(11)$ & 0 \\
$c_{13}$ & $(12)$ & 0.0661381 \\
$c_{14}$ & not for black alder & \\
$c_{15}$ & not for black alder & \\
$c_{16}$ & not for black alder & \\
$c_{17}$ & not for black alder & \\
$c_{18}$ & $(15)$ & 0.2817561 \\
$c_{19}$ & $(16)$ & 0.6605342 \\
$c_{20}$ & $(16)$ & 0.0000000 \\
$c_{21}$ & $(16)$ & 1.1158148 \\
$c_{22}$ & $(16)$ & 0.0000000 \\
$c_{23}$ & $(16)$ & 0.8000000 \\
$c_{24}$ & $(17)$ & 0.9928610 \\
$c_{25}$ & $(18)$ & 1.9019300 \\
$c_{26}$ & $(18)$ & 0.8448800 \\
$c_{27}$ & $(18)$ & -2.5507000 \\
$c_{28}$ & $(19)$ & 0.9115378 \\
$c_{29}$ & $(19)$ & 1.0049721 \\
$c_{30}$ & $(19)$ & 0.7388343 \\
$c_{31}$ & $(19)$ & 0 \\
$c_{32}$ & $N_{0}$ & 5000 \\
$c_{33}$ & & \\
& & \\
\hline
\end{tabular}

In Paragraaf 6.3 worden enkele eigenschappen van de uiteindelijk tabellen vergeleken met andere opbrengsttabellen. In Bijlage 1 zijn de geproduceerde opbrengsttabellen weergegeven. 


\subsection{Vergelijking met andere opbrengsttabellen}

Hierna zijn enkele andere opbrengsttabellen (of alleen de hoogteontwikkeling) voor de zwarte els in Europa vergeleken met het hier gevonden resultaat, dat betreffen de hoogteontwikkeling bij Thibaut et al., 2004 voor Zuid-België, de tabel van Mitscherlich (1945, In: Schober 1987) voor Duitsland, de tabel van Lockow (1993, de tabel van Korsun (1966) voor Tsjechië en die van Sopp (1974) voor Hongarije (bij Korsun en Sopp is alleen de hoogte- en volumeontwikkeling beschikbaar). Voor Nederland is er een tabel van Jansen et al. (1996) beschikbaar, dit is een bewerking van de tabel van Mitscherlich (1945) voor Duitsland.

\subsubsection{Hoogteontwikkeling}

Thibaut et al. (2004) heeft vijf boniteiten met een hoogteontwikkeling die steiler is dan die van de nieuwe tabellen voor Nederland (zie Figuur 9). Tussen de 20 en 65 jaar stijgt de boniteit er één eenheid ten opzichte van de nieuwe boniteit.

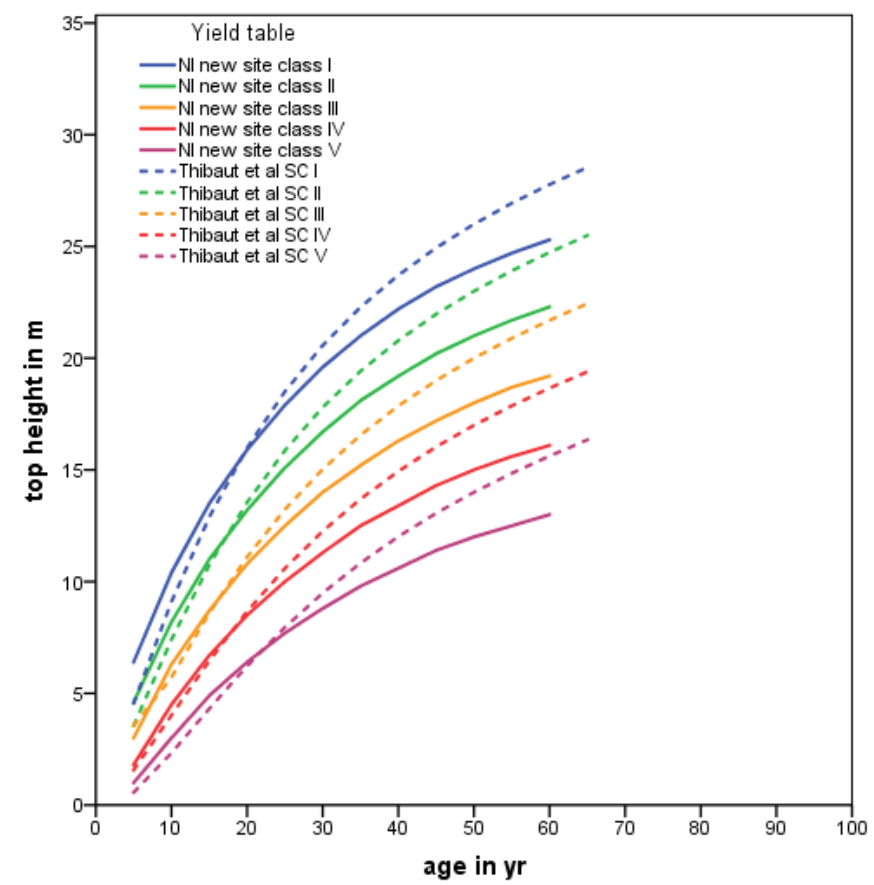

Figuur 9. Hoogteontwikkeling bij Thibaut et al. en het nieuwe model voor Nederland.

Figure 9. Height development at Thibaut's et al. site curves and the new model for Netherlands.

Mitscherlich (1945) onderscheidt 3 boniteiten waarbij hoogteontwikkeling van de II boniteit nagenoeg exact met die van de $I^{\mathrm{e}}$ boniteit van de nieuwe tabel voor Nederland overeenkomt. De betere boniteiten hebben bij Mitscherlich vanaf 60 jaar een iets steilere curve (zie Figuur 10a).

Lockow (1993) heeft maar één boniteit die vanaf 30 jaar exact met de curve van de $\mathrm{I}^{\mathrm{e}}$ boniteit van de nieuwe tabel voor Nederland overeenkomt, daarvoor komt de groei wat langzamer op gang (zie Figuur 10b) 

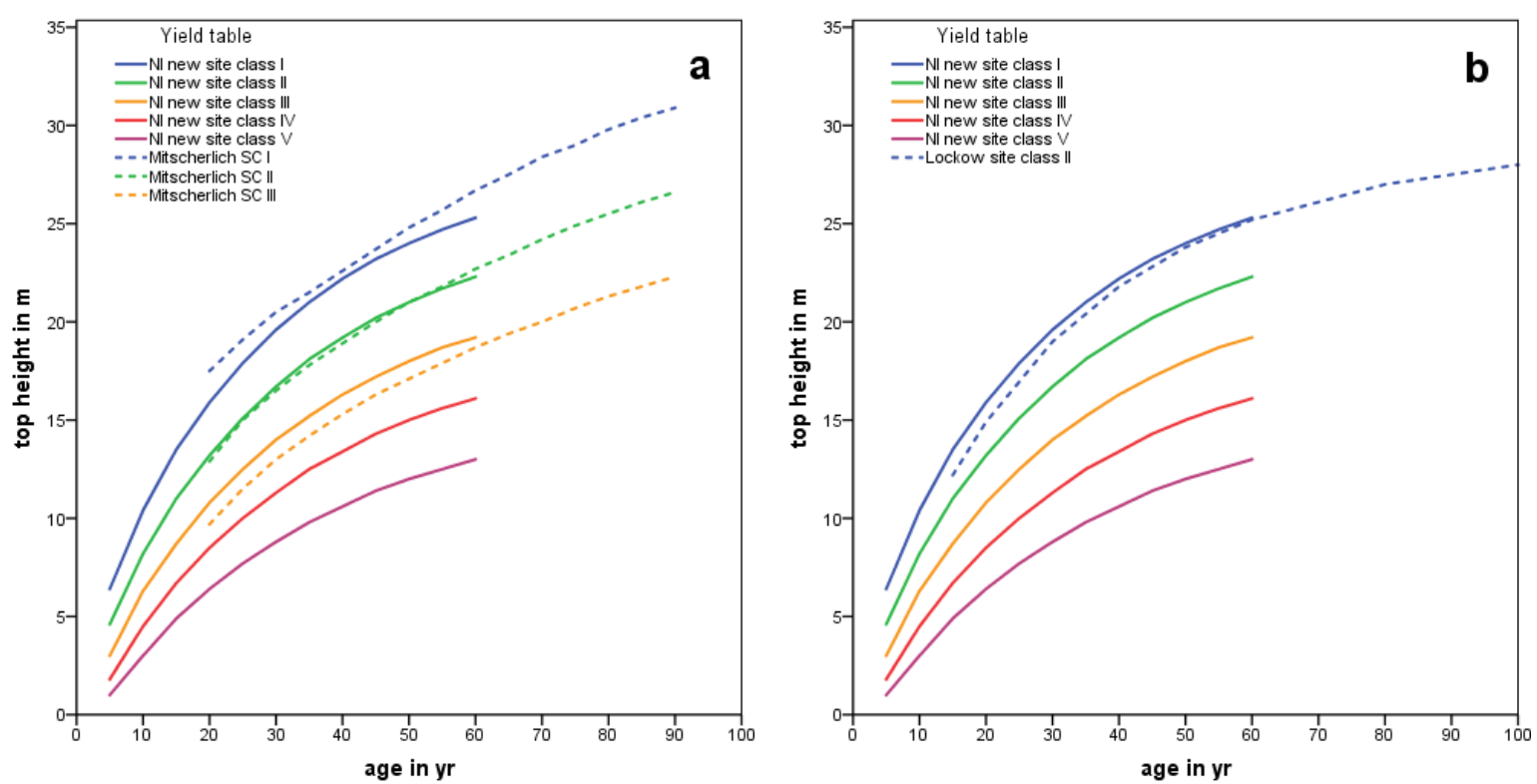

Figuur 10. Hoogteontwikkeling in Duitsland bij Mitscherlich (a) en Lockow (b) en het nieuwe model voor Nederland.

Figure 10. Height development in Germany at Mitscherlich's (a) and Lockow's yield tables (b) and the new model for Netherlands.

Jansen et al. (1996) onderscheiden 5 boniteiten. Het bereik van de nieuwe tabel voor Nederland is ruimer naar de slechtste boniteit toe. De hoogteontwikkeling vanaf 20 jaar is nagenoeg gelijk aan die van de nieuwe tabel voor Nederland (zie Figuur 11).

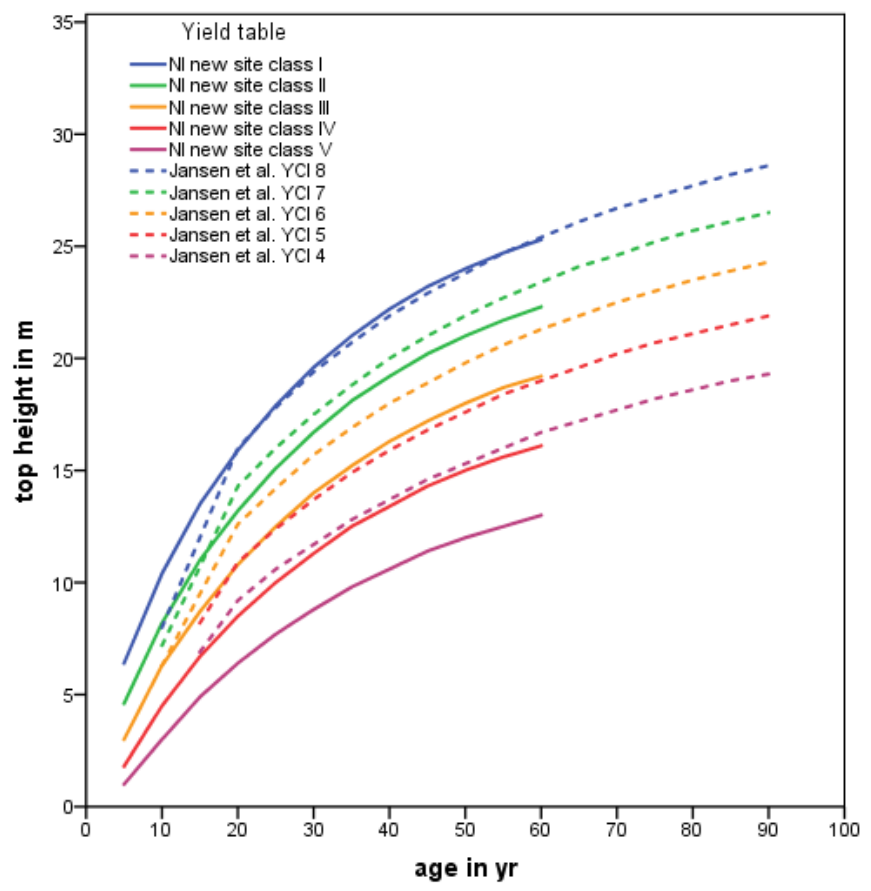

Figuur 11. Hoogteontwikkeling bij Jansen et al. en het nieuwe model voor Nederland. Figure 11. Height development at Jansen et al. yield table and the new model for Netherlands. 
Bij de opbrengsttabel van Sopp (1974) voor Hongarije komt de vorm van de curven zeer goed overeen met die van het nieuwe model voor Nederland (zie Figuur 12). Zijn I boniteit komt ongeveer overeen met $\mathrm{O}^{\mathrm{e}}$ boniteit bij het nieuwe model voor Nederland.

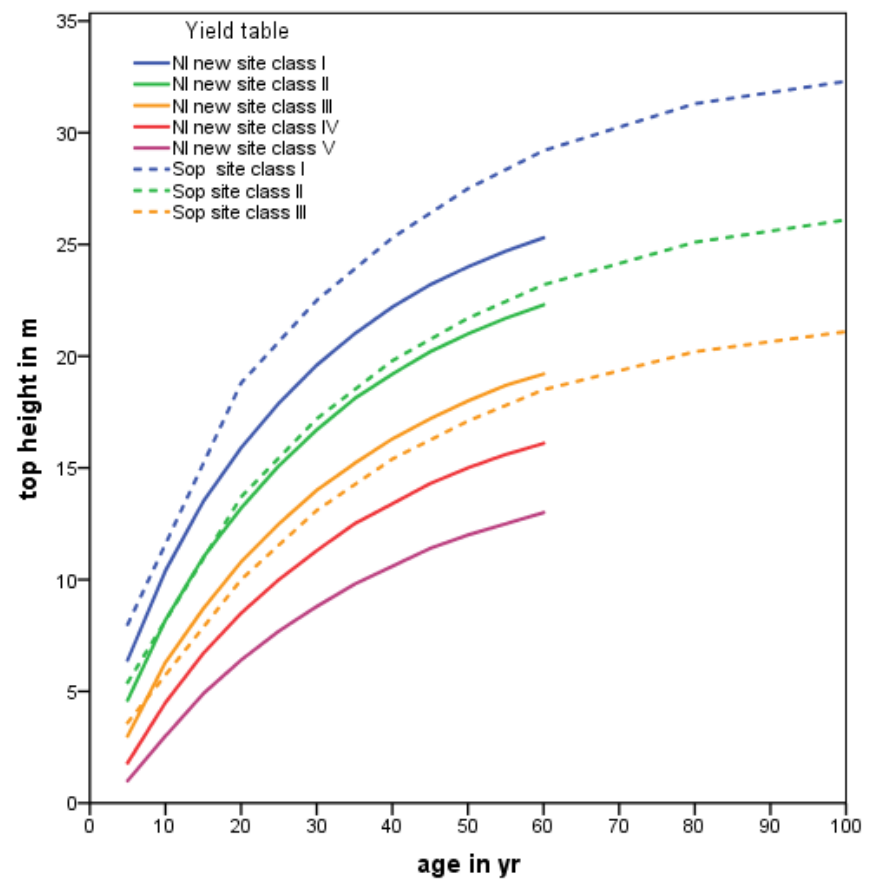

Figuur 12. Hoogteontwikkeling bij Sopp en het nieuwe model voor Nederland.

Figure 12. Height development at Sopp's yield table and the new model for Netherlands.

Er blijkt zeer weinig overeenkomst met de opbrengsttabel voor Korsun (1966) voor Tsjechië (zie Figuur 13).

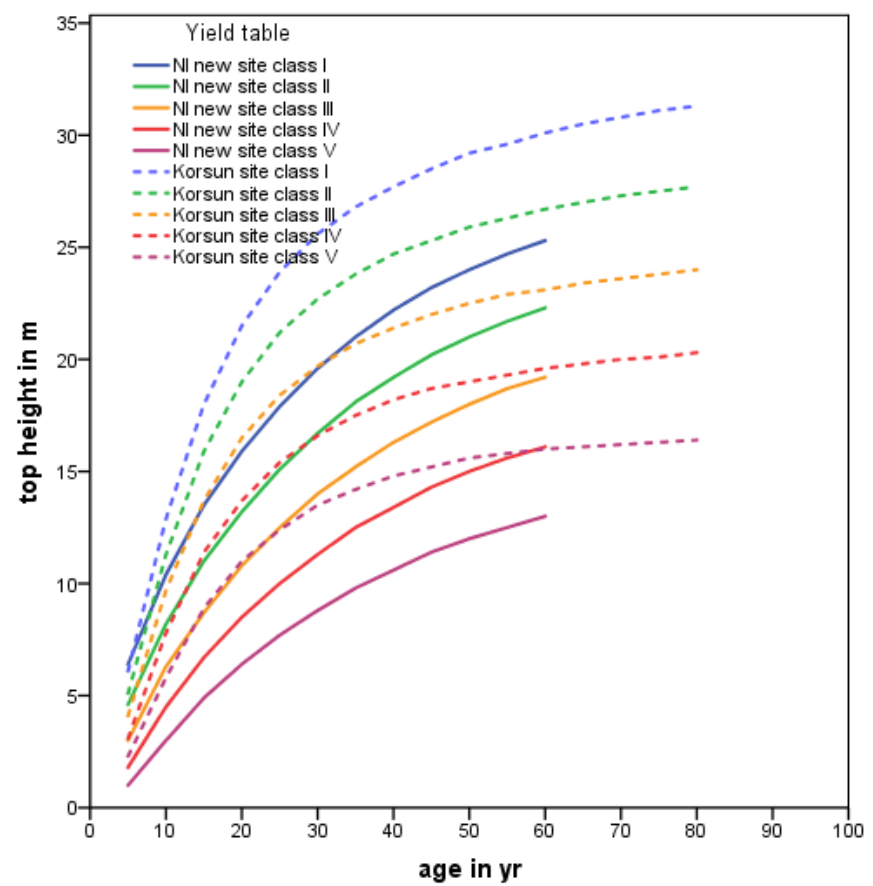

Figuur 13. Hoogteontwikkeling bij Korsun en het nieuwe model voor Nederland.

Figure 13. Height development at Korsun's yield table and the new model for Netherlands. 
Er blijken dus veel gemeenschappelijke punten met de nieuwe tabel voor Nederland en de meeste vergeleken tabellen, die overeenkomst was er niet bij Korsun. Ook bij Thibaut et al., zijn er grote verschillen, daar hoort wel een kanttekening bij, Thibaut et al. geven meerdere modellen voor verschillende standplaatsen en de vergelijking heeft alleen betrekking op een gemiddelde standplaats.

\subsubsection{Productieniveau}

Het productieniveau wordt bij voorkeur gemeten op basis van de gemiddelde volumebijgroei bij zekere leeftijd. Hier is echter naar de totale grondvlakproductie gekeken.

In Figuur 14 is de totale grondvlakproductie per opbrengsttabel uitgezet tegen de opperhoogte voor alle boniteiten. De meeste opbrengsttabellen hebben als startpunt een hoogte tussen 7 tot $17 \mathrm{~m}$, en de nieuwe tabel vanaf $1.3 \mathrm{~m}$.
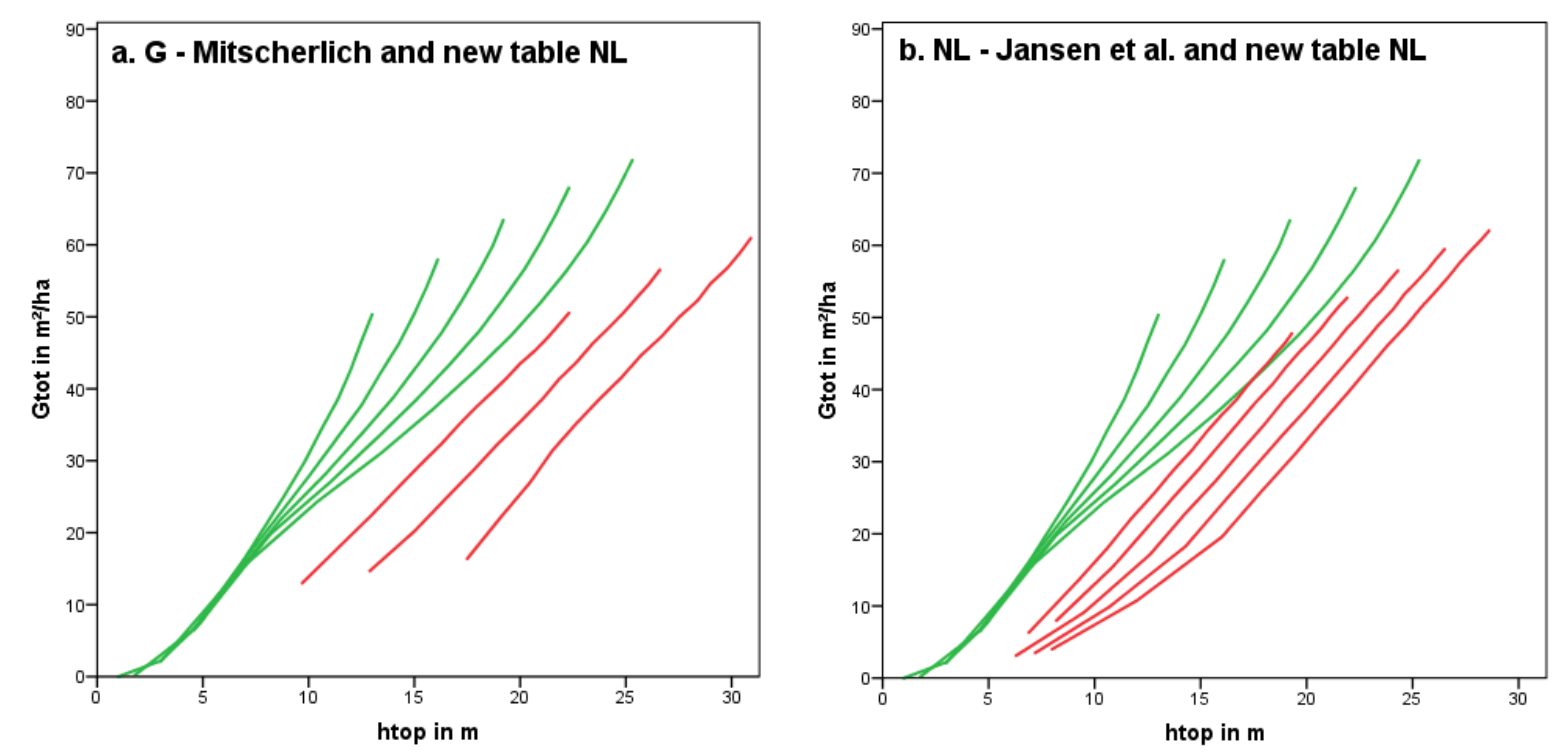

Figuur 14. De totale grondvlakproductie Gtot in relatie tot de opperhoogte bij de nieuwe tabel voor Nederland (in groen) in vergelijking met andere opbrengsttabellen (in rood) voor Mitscherlich (a) en Jansen et al. (b).

Figure 14. Total basal area production Gtot and top height for the new yield table (in green) in comparison with other yield tables (in red) by Mtscherlich (a), Jansen et al. (b)

De hellinghoeken bij Mitscherlich en bij Jansen et al. komen redelijk overeen met die van de $3^{\mathrm{e}}$ boniteit van de nieuwe tabel. Het aanvangsniveau bij Mitscherlich ligt veel lager omdat de tabellen op veel latere leeftijd beginnen met lagere stamtallen, waardoor vroege dunning niet zijn begrepen in de totale grondvlakproductie. Hetzelfde geldt voor de opbrengsttabel van Jansen et al. 


\section{Discussie en conclusies}

\subsection{Hoogtegroei}

De hoogteontwikkeling van de opstand is een resultante van hoogtegroei en topsterfte. Een biologisch relevant groeimodel moet een buigpunt en een asymptoot hebben. Bij het schatten van de parameters van de verschillende modellen met de 12 plots van Figuur 1a werd geen aanvaardbare oplossing gevonden. Daarom is gebruik gemaakt van die data van de $4^{e}$ Bosstatistiek (CBS, 1985) door daar 4 groepen in te onderscheiden die als kunstmatige plots zijn behandeld. Een punt van zorg is feit dat die groepen niet onafhankelijk van het model zijn te bepalen. Dus ieder model genereert een eigen groepsindeling. Met een MCA zijn de resultaten van de analyses vergeleken en het model van Jansen \& Hildebrand is gekozen:

$$
h_{\text {top }}=S \cdot\left(1-e^{-c_{1} \cdot t}\right)^{\left(c_{2}-c_{3} \cdot S\right)}
$$

Met de 12 echte plots en de 4 kunstmatige plots samen zijn uiteindelijk de parameters van (20) geschat.

Voor boniteren geldt dan:

$$
\rightarrow h_{50}=S \cdot\left(1-e^{-c_{1} \cdot 50}\right)^{\left(c_{2}-c_{3} \cdot S\right)} \text { and } S=h_{50} \cdot\left(1-e^{-c_{1} \cdot 50}\right)^{\left(-c_{2}+c_{3} \cdot S\right)}
$$

De asymptoot, hier de site index $S$ genoemd, is een maat voor de geschiktheid van de standplaats (boniteit) voor de zwarte els, in de praktijk wordt echter $h_{50}$ als maat voor de boniteit gebruikt. Boniteren is met dit model lastig, want vereenvoudigd staat in Formule (21) $h_{50}=f\left(h_{\text {top }}, t, h_{50}\right)$, je moet dus met een startwaarde voor $h_{50}$ werken en iteratief naar een oplossing werken.

De $R^{2}$ adj bleek met een waarde van 0.972 aan lage kant, en lager dan in de meeste eerdere studies werd gevonden, maar deze waarde is veel hoger dan de $R^{2}$ adj met alleen met gebruik van de 12 permanente plots, die bedroeg namelijk 0.889 .

\subsection{Diameter en grondvlak}

In Paragraaf 4.2 is het model voor de lopende bijgroei van het grondvlak ontwikkeld. Dit model start na het bereiken van een opperhoogte van $7 \mathrm{~m}$. In Paragraaf 7.2.2 wordt hierop ingegaan. Om een startwaarde voor de diameter voor dunning en het grondvlak per ha voor dunning te hebben op het tijdstip $t_{7}$ is in Paragraaf 4.1 een model ontwikkeld voor de diameterontwikkeling. In Paragraaf 7.2.1 wordt dit besproken.

\subsubsection{Diameterontwikkeling}

In Paragraaf 4.1 is het model Jansen et al. (2016) voor de diameterontwikkeling gebruikt, in vereenvoudigde vorm luidt dit: 


$$
\begin{gathered}
d_{b t}=f_{2}\left(h_{\text {top }}, d_{7}\right) \text { for } h_{\text {top }} \leq 7 \\
\text { where } d_{7}=f_{1}\left(N_{0}\right) \quad \text { (the diameter at a height of } 7 \mathrm{~m} \text { ) } \\
N_{0}=\text { initial number of trees }
\end{gathered}
$$

Voor dit traject waren alleen de data van de $4^{\mathrm{e}}$ Bosstatistiek beschikbaar, hier ontbreekt $N_{0}$, en daarom werd $d_{7}$ geschat als een parameter. Gevonden werd $d_{7}=6.5$. Vergelijking met andere opbrengsttabellen bleek niet mogelijk.

\subsubsection{Grondvlakbijgroei}

In Paragraaf 4.2 werd Formule (11) voor de grondvlakbijgroei gevonden, in vereenvoudigde vorm luidt dit:

$$
\begin{aligned}
i_{G, i j k}= & f_{1}(S \%) \cdot\left\{\frac{F_{3}\left(h_{2}, t_{2}\right)-F_{3}\left(h_{1}, t_{1}\right)}{t_{2}-t_{1}}\right\} \\
& \text { for the } j^{\text {th }} \text { plot at age } i=t_{m}=\left(t_{1}+t_{2}\right) / 2 \text { in the } k^{\text {th }} \text { year of recording }
\end{aligned}
$$

Een power-functie voor $F_{3}$ het meest geschikt. Net als bij de douglas (Jansen et al. 2016) stijgt de grondvlakbijgroei met toenemende boniteit, de stijging is alleen een gevolg van $F_{3}$. De term voor de hoogte in $F_{3}$ bleek niet significant. De correctiefactor voor de grondvlakbijgroei $f_{1}$ is actief vanaf een $S \%$ van ongeveer 15.6. Er waren zeer weinig data, twee plots zijn uitgesloten van de analyse wegens gigantisch uitbijter gedrag, ondanks dat er maar 18 vrijheidsgraden waren bleek de $R^{2}$ adj is vrij hoog.

Bij de externe controle is de relatie tussen $G_{\text {tot }}$ en $h_{\text {top }}$ bekeken, de hellinghoek van de lijnen bleken in de vergeleken opbrengsttabellen redelijk overeen te komen. Het aanvangsniveau verschilde wel.

\subsection{Dunning}

Om de dunning te kwantificeren is een dunninggraad gebruikt. De in Duitsland gebruikelijke indeling met een $A$ - tot en met $D$-graad gebaseerd op het dunnen van bomen behorend tot een of meerdere Kraftse boomklassen is in Nederland nooit aangeslagen. Becking (1953) vindt deze methode te weinig kwantitatief en kiest voor een $S$ \% (volgens Hart, 1928) van 16 $\%$ voor een zwakke laagdunning, met $3 \%$ erbij is dan sprake van de volgende dunninggraad, namelijk bij $19 \%$ een matige laagdunning. In Tabel 9 is een volledig overzicht van het $S \%$ en de bijbehorende namen. In andere opbrengsttabellen is een geleidelijk toename een bepaald $S \%$ te zien vanaf ongeveer 50 jaar. Dit is logisch omdat op latere leeftijd de kroonvorm verandert, waardoor bij gelijkblijvende standruimte een hogere $S \%$ nodig is. De mate van deze verandering kon niet geschat worden en de gemiddelde waarde van drie vergeleken opbrengsttabellen is in Formule (12) weergegeven. Het ratiomodel (14) van La Bastide en Faber (1972) is gebruikt waarbij de ratio een constante factor is. 


\subsection{Kwaliteit van het model}

In Tabel 13 is de groeiklasse per boniteit aangegeven in vergelijking met andere opbrengsttabellen. Deze groeiklasse is het totaal geproduceerde (en deels geoogste) gemiddelde spilhoutvolume in $\mathrm{m}^{3} \mathrm{ha}^{-1} \mathrm{jr}^{-1}$ bij een leeftijd van 50 jaar. De nieuwe tabel past binnen de range van de vergeleken tabellen, maar er is weinig eenduidigheid.

Tabel 13. Groeiklasse per dunninggraad en boniteit.

Table 13. Yield class (mean annual volume increment at $50 \mathrm{yr}$.) per thinning grade and site class.

\begin{tabular}{|c|c|c|c|c|c|c|}
\hline \multirow{2}{*}{ Yield table } & \multirow{2}{*}{ Thinning grade } & \multicolumn{5}{|c|}{ Boniteit } \\
\hline & & I & II & III & IV & V \\
\hline New table Netherlands & moderate & 10.8 & 9.4 & 7.9 & 6.4 & 4.8 \\
\hline Mitscherlich $^{1)}, 1945$ & extra heavy & 8.5 & 6.4 & 4.4 & & \\
\hline Sopp ${ }^{2)}, 1974$ & heavy & 14.0 & 11.0 & 4.9 & & \\
\hline Lockov $^{2)}, 1993$ & heavy & 8.9 & & & & \\
\hline Korsun $^{3)}, 1966$ & moderate & 11.5 & 9.4 & 7.3 & 5.2 & 3.1 \\
\hline Jansen et al., 1996 & extra heavy & 7.9 & 7.0 & 6.0 & 5.0 & 4.0 \\
\hline
\end{tabular}

1) In Schober, 1986

2) In Claessens et al., 2010

3) In AFOLU DATA, JRC, 2016

Maar aangezien de boniteitindeling per tabel nogal verschilt, zoals blijkt uit de Figuren 11 $\mathrm{t} / \mathrm{m} 13$ is ook een grafische weergave gemaakt van de groeiklasse $\left(\operatorname{Im} V_{50}\right)$ per $h_{50}$ in Figuur 15

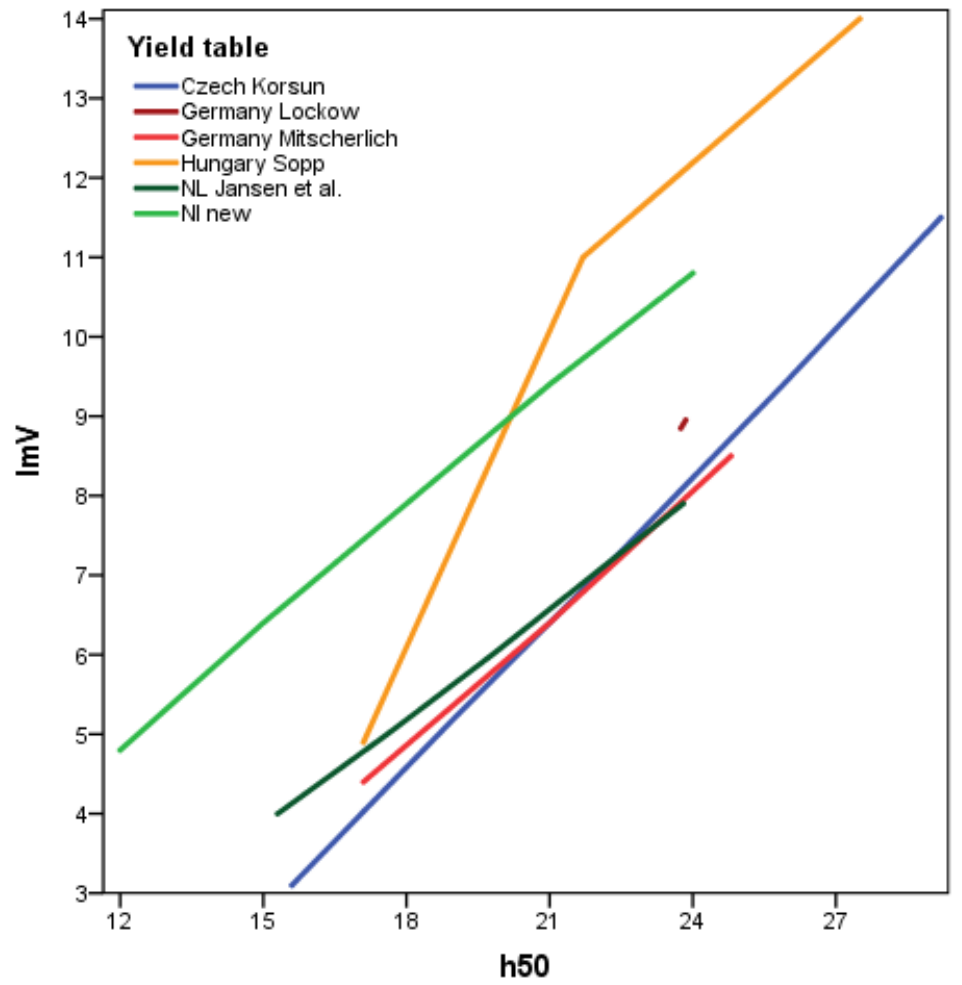

Figuur 15. Productieniveau in relatie tot boniteit bij diverse opbrengsttabellen. Figure 15. Production level in relation to site index for various yield tables. 
De verschillen blijken groot enerzijds is er groep tabellen waar het productieniveau vergelijkbaar en laag is (Mitscherlich, Lockow, Korsun en Jansen et al., maar ook de III boniteit bij Sopp), anders een hoog niveau (Sopp boniteit II en III). Het niveau van de nieuwe tabel voor Nederland valt daartussenin. In Paragraaf 4.2 is vermeld dat er 2 proefperken zijn uitgesloten van de analyse. De vraag is of dat van invloed kan zijn op de resultaten. In Figuur 16 is een kopie van Figuur 8a opgenomen waarbij de beide uitgesloten plots in rood zijn gemarkeerd.

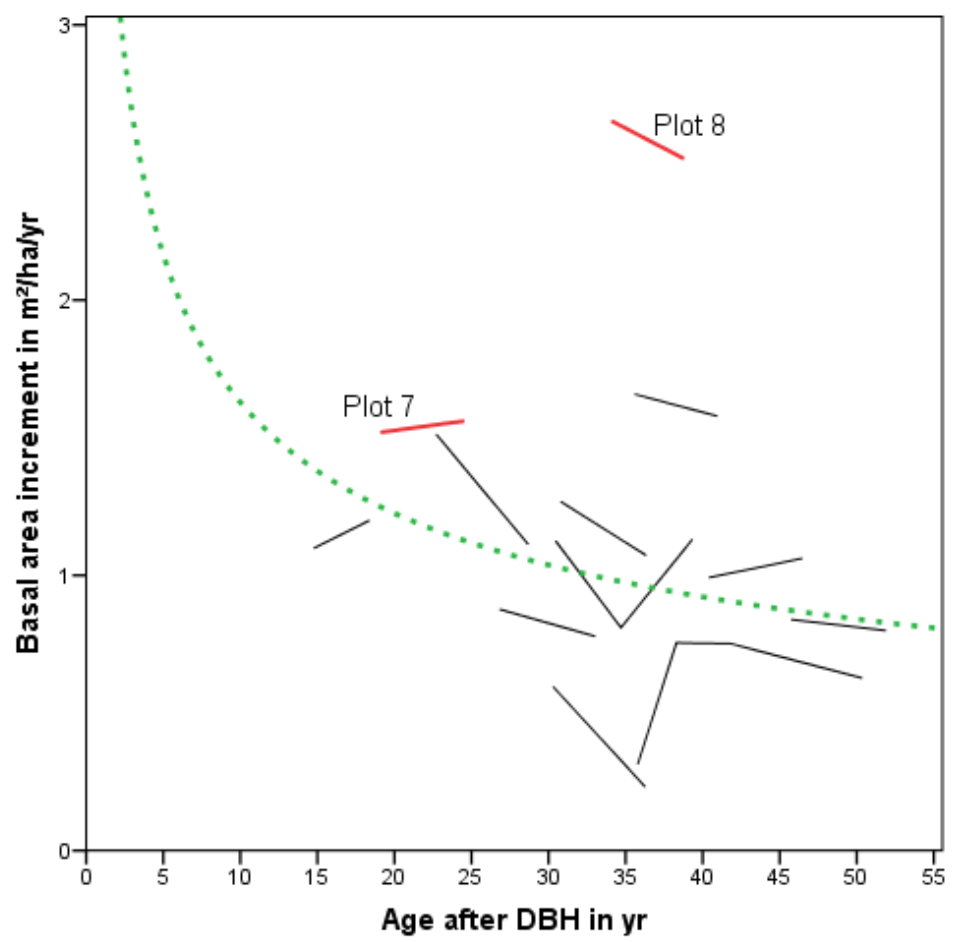

Figuur 16. Grondvlakbijgroei als functie van de leeftijd. De zwarte en rode lijnen geven het verloop binnen één plot aan, waarbij de rode lijnen zijn uitgesloten van de analyse, de groene lijn de beste fit voor een power-functie over alle opnamen.

Figure 8. The basal area increment as a function of age. The black and red lines represent the course within a plot, of which the red ones are excluded from analyses. The green line represents the best fit with a power function for all recordings.

Het uitgesloten Plot 8 blijkt een zeer hoog productieniveau te hebben en Plot 7 bleek vooral een uitbijter te zijn ten opzichte van het $S \%$ te zijn, dus geen reden te veronderstellen dat het productieniveau door deze uitsluiting wordt overschat. Volgens Verweij (1983) is er sprake van twee genotypische varianten van de zwarte els in Nederland, bij gebrek aan dat kon niet onderzocht worden of dit een rol speelt bij de analyse.

Een ander punt van aandacht is of de opbrengsttabel voldoende dekkend is voor alle zwarte els in Nederland.

In Tabel 4 blijkt dat het totale bereik voor de $h_{50} 10.5$ tot $25.5 \mathrm{~m}$ bedraagt voor de boniteiten I tot V. De hoogst geschatte $h_{50}$ bij de data van de $4^{\mathrm{e}}$ Bosstatistiek bedroeg $24.0 \mathrm{~m}$ en de hoogst geschatte $S$-waarde bedroeg $33.2 \mathrm{~m}$. 
Volgens https://www.monumentaltrees.com/nl/hoogterecords/nld/ (geraadpleegd 02-012018) staat de hoogste zwarte els ( 33.0 m met een leeftijd van ca 120 jaar) van Nederland in Sonsbeek te Arnhem. De $S$-waarde van een opstand met gelijke hoogte en leeftijd zou dan $33.9 \mathrm{~m}$ moet zijn. Dat is net buiten het bereik van de opbrengsttabel. De kans dat er standplaatsen in Nederland zijn waar het groeimodel niet toepasbaar is lijkt daarom onwaarschijnlijk, wel zijn er standplaatsen met een betere boniteit dan de $\mathrm{I}^{\mathrm{e}}$. en een slechtere boniteit dan de $V^{e}$, dat gaat in totaal om $2.2 \%$ van het Nederlandse bosareaal. 


\section{Samenvatting}

Dit is een rapport over de groei en productie van de zwarte els (Alnus glutinosa) in Nederland. Er is onderzocht hoe de ontwikkeling van de hoogte, diameter en het grondvlak in de tijd is geweest en hoe deze beïnvloed wordt door de dunning. Met de gevonden relaties en andere allometrische relaties is een set opbrengsttabellen opgesteld voor een matige laagdunning.

De gebruikte dataset betreft de gegevens die tussen 1965 en 1990 in Nederland in groei- en productieonderzoek bij de zwarte els zijn verzameld door voormalige Dorschkamp/IBN; dit omvat 2 proefperken met 8 opnamen en 2 proefperken met 10 opnamen uit een herkomstproef met alleen de hoogtewaarnemingen. Daarnaast zijn 10 plots met 31 opnamen uit de HOSP gebruikt. Ook de hoogte- en diameterschattingen in 518 elzenopstanden uit de $4^{\mathrm{e}}$ Bosstatistiek zijn gebruikt.

Per opname zijn leeftijd, opnamedatum en opperhoogte bekend en per toestand voor, na en van de dunning stamtal, grondvlak, diameter, hoogte en volume.

De hoogteontwikkeling is onderzocht met vijf bekende groeimodellen en bleek het best te verklaren met het model van Jansen et al.(1996), dit heteromorfe model bestaat uit twee delen: vanaf een hoogte van $7 \mathrm{~m}$ is het model van Jansen \& Hildebrand gebruikt er geldt: $h_{\text {top }}=S \cdot\left(1-e^{-a \cdot t}\right)^{b}$. Hierin is $S$ een proefperkspecifieke parameter en maat voor een absolute hoogteboniteit, $a$ een soortspecifieke parameter en $b$ afhankelijk van de waarde van $S$. Voor praktisch gebruik wordt $h_{50}$ als maat voor de boniteit gebruikt. Voor de ontwikkeling tot $7 \mathrm{~m}$ is een Korf-functie gebruikt, er geldt: $h_{\text {top }}=S_{k} \cdot e^{-a_{k} \cdot t^{-b_{k}}}$, Het hoogtegroeimodel is uiteindelijk herschreven om een vloeiende aansluiting van de twee functies bij $t=7$ te bewerkstelligen. Omdat er zeer weinig waarnemingen waren, met name bij de slechte boniteiten zijn data van de $4^{\mathrm{e}}$ bosstatistiek als volgt gebruikt. Met behulp van voortschrijdende gemiddelden zijn de data van de $4^{\mathrm{e}}$ Bosstatistiek in 4 subgroepen ingedeeld en de gemiddelden per groep resulteerden in vier chronoseries, die als kunstmatige proefperken aan de data zijn toegevoegd. Met nu 18 proefperken en dus 4 extra lange proefperken werd met een $R^{2}$ adj van 0.988 een oplossing gevonden.

De hoogteontwikkeling bij Mitscherlich (1945) en Lockow (1993) in Duitsland en Jansen et al. (1996) voor Nederland vertonen grote overeenkomst. De hoogteontwikkeling Thibaut et al. (2004) voor België is steiler. De hoogteontwikkeling bij Sopp (1974) voor Hongarije is nagenoeg gelijk aan die van het nieuwe model voor Nederland, maar kent betere boniteiten. De hoogteontwikkeling bij Korsun (1966) voor Tsjechië vertoont geen enkele overeenkomst.

De diameterontwikkeling tot een hoogte van $7 \mathrm{~m}$. werd het best verklaard met het model van Jansen et al. (2016) $d_{b t}=d_{7} \cdot f\left(h_{\text {top }}\right)$. In dit model in $d_{7}$ normaliter een functie van $N_{0}$, maar nu alleen een te schatten parameter. De $R^{2}$ adj bleek 0.806 en $d_{7}=6.5 \mathrm{~cm}$. Voor het traject boven een hoogte van $7 \mathrm{~m}$ is de grondvlakbijgroei gemodelleerd met een ander model van Jansen et al. (2016): $i_{G}=f\left(h_{50}, h_{\text {top }}, t, S \%\right.$,yor $)$ waarbij gebruik gemaakt is van een powermodel. Voor $S \%>15.7$ daalt de grondvlakbijgroei niet-lineair, met gemiddeld $4.0 \%$ per $S \%$ verschil. De $R^{2}$ adj is 0.457 . Het jaar van opname (yor), de boniteit $\left(h_{50}\right)$ en $h_{\text {top }}$ bleken niet significant.

Het effect van de dunning op de diameter na dunning $\left(d_{a t}\right)$ is gemodelleerd met het La Bastide-Faber model (1972). 
Met de geïntegreerde modellen is een opbrengsttabel gemaakt voor een leeftijd tot 60 jaar met 5 boniteiten en een matige laagdunning. Het productieniveau is vergeleken met dat van tabellen voor Duitsland, Tsjechië en Hongarije, er waren grote verschillen, maar het niveau van de nieuwe tabellen voor Nederland paste binnen die range. Wel is het aan de hoge kant van die range.

Op hoofdlijnen bleek het model van Jansen et al. (2016) voor de douglas ook bruikbaar voor de zwarte els. 


\section{Summary}

This report describes growth and yield of black alder (Alnus glutinosa) in Netherlands. The report describes the development of height, diameter and basal area over time, based on permanent field plots, and the effect of thinning on these characteristics. The regularities and allometric relationships found were used to construct a yield table for even-aged stands of black alder.

The dataset used in this study is composed of growth and yield related research on black alder in the Netherlands, carried out between 1965 and 1990 by the former Dorschkamp/IBN research institute, and includes 2 experimental plots and 2 provenance trials. Furthermore, 10 sample plots from the 4th Dutch National Forest Inventory and from the timber prognosis system HOSP, were used. In total, the dataset consists of 14 plots with 49 recordings. Height recordings in 518 black alder stands from the 4th Dutch National Forest Inventory were also used. Each plot record includes age, recording date and top height, as well as stem density, basal area, diameter, height and volume before and after thinning and of the thinning itself.

The height development has been studied with five well-known growth models and proved to be best explained with the Jansen \& Hildebrand modification of the Chapman-Richards function: $h_{\text {top }}=S \cdot\left(1-e^{-a \cdot t}\right)^{b}$. Where $S$ is a plot specific parameter and a measure for a site index, $a$ is a species specific parameter, $b$ is dependent on the value of $S$. The model creates a system of polymorphic height development curves. For heights below $7 \mathrm{~m}$ the model of Korf performed better: $h_{\text {top }}=S_{k} \cdot e^{-a_{k} \cdot t^{-b_{k}}}$. The height growth model was finally rewritten with a smooth connection of the two functions at $t=7$. To improve the results the data from the black alder stands from the Fourth Dutch National Forest Inventory were split up in 4 subgroups, using a moving average technique. The average height values per age for each group resulted in four chronosequences, which have been added to data set as four artificial plot. With now 18 plots (including 4 extra long ones) a solution was found with an $R^{2}$ adj of 0.988 .

The height development was compared with the models Mitscherlich (1945) and Lockow (1993) for Germany, Thibaut et al. (2004) for Belgium, Korsun (1966) for the Czech Republic, Sopp (1974) for Hungary and Jansen et al. (1996) for the Netherlands. There was a reasonable match with Mitscherlich's, Lockow's, Sopp's and Jansen's height development models, but a mismatch Thibaut's and Korsun's models.

The diameter development (before thinning: $d_{b t}$ ) to a height of $7 \mathrm{~m}$ was described by the model of Jansen et al. (2016) $d_{b t}=d_{7} \cdot f\left(h_{\text {top }}\right)$. In this model $d_{7}$ is a function of the initial number of trees $N_{0}$. But due to a lack of observations in the permanent plots, 386 recordings of the Fourth Dutch National Forest Inventory were used without information about $N_{0}$. With $R^{2}$ adj $=0.806, d_{7}$ was estimated to be $6.9 \mathrm{~cm}$. The model was only used for diameter and basal area development up to a height of $7 \mathrm{~m}$. For the development above $7 \mathrm{~m}$, basal area increment was described using the model of Jansen et al (2016): $i_{G}=f\left(h_{50}, h_{\text {top }}, t, S \%, y o r\right)$, using a power function. For the Becking-Hart spacing index $S \%$ larger than 15.7, basal area increment decreased nonlinearly with $S \%$, with about $4 \%$ per unit. The $R^{2}$ adj was 0.457 . The $h_{50}, h_{\text {top }}$ and the year of recording (yor) were not significant, and the model does not follow Eichhorn's law. The effect of thinning on diameter after thinning $\left(d_{a t}\right)$ was modelled with La Bastide \& Faber's model (1972). 
Using the integrated models, a yield table was created for even-aged stands of ages up to 80 years, using five site classes. The yield table was compared with tables from Germany, Czech Republic and Hungary. The production level of all these tables showed considerable variation, and the growth level of the new table for the Netherlands was within the range of values reported elsewhere. Overall, the model of Jansen et al. (2016) for Douglas fir turned out to be suitable also for black alder. 


\section{Literatuur}

Bartelink, H.H., A.F.M. Olsthoorn, A. Oosterbaan \& S.M.J. Wijdeven, 2001. Overzicht van een eeuw onderzoek naar groei en opstandsontwikkeling in relatie tot groeiplaats en beheer. Alterra, Research Instituut voor de Groene Ruimte, Wageningen, Alterrarapport 256.

Becking, J. H., 1953. Thinning research in forestry. Netherlands Journal of Agricultural Science; 1953. 1(2):122-9.

Burkhart, H,E. \& R.B. Tennent, 1977. Site index equations for radiata pine in New Zealand. New Zealand Journal of Forestry Science 7: 408416.

C.B.S. (Centraal Bureau voor de Statistiek),1985. De Nederlandse Bosstatistiek, deel 1: de oppervlakte bos,1980 1983. Staatsuitgeverij, s'Gravenhage

Cieszewski C.J., 2001. Three methods of deriving advanced dynamic site equations demonstrated on inland Douglas-fir site curves. Can. J. For. Res. 31: 165-173 .

Claessens, H. A. Oosterbaan, P. Savill, J. Rondeux, 2010. A review of the characteristics of black alder (Alnus glutinosa (L.) Gaertn.) and their implications for silvicultural practices. Forestry 83(2): 163-175

Goudzwaard, L., J.J. Jansen, A. Oosterbaan, J.F. Oldenburger, G.M. Mohren \& J. den Ouden, 2016. FEM growth and yield data Monocultures - Other species. DANS:

http://dx.doi.org/10.17026/dans-xc2-f34x.

Hart, H.M.J., 1928. Stamtal en dunning : een orienteerend onderzoek naar de beste plantwijdte en dunningswijze voor den djati. Proefschrift Wageningen. Mededeelingen Proefstation voor het Boschwezen (21) 219 p. + 7 bijl. Veenman, Wageningen.

Heisterkamp, S.H., 1981. Opstandsinhoudsfuncties. Rapport Rijksinstituut voor onderzoek in de bos- en landschapsbouw "De Dorschkamp" 271, Wageningen.

IUFRO, 1959. The standardization of symbols in forest mensuration. International Union of Forest Research Organizations, Londen.

Jansen, J.J. \& J.W. Hildebrand, 1986. Een nieuwe opbrengsttabel voor de fijnspar (Picea abies Karst.) in Nederland. Landbouwhogeschool, Vakgroep Boshuishoudkunde, Wageningen.

Jansen, J.J., J. Sevenster \& P.G. Faber (redactie), 1996. Opbrengsttabellen voor belangrijke boomsoorten in Nederland. IBN rapport 96/Hinkeloord reports No.17, 202 pag.

Jansen, J.J., H. Schoonderwoerd, G.M.J. Mohren \& J. den Ouden, 2016. Groei en productie van douglas in Nederland. Becking's dunningproeven ontsloten. Wageningen Academic Publishers.

Jansen, J.J., G.M.J. Mohren, A. Oosterbaan , L. Goudzwaard en J. den Ouden, 2018. Groei en productie van beuk in Nederland. FEM Groei en productie rapport 2018 - 5, Wageningen Universiy.

Korsun, F. 1966. Volume and yield tables for alder. Lesnicky casopis Praha 12(9): 839-856. In: Joint Research Centre (JRC), 2016. AFOLU DATA. https://ec.europa.eu/jrc/en/scientific-tool/afolu-data-portal I

La Bastide, J.G.A. \& P.J. Faber, 1972. Revised yield tables for six tree species in the Netherlands. Uitvoerig Verslag Bosbouwproefstation "De Dorschkamp", band 11, nr. 1.

Lockow, K.-W., 1993. A yield table for red alder (Alnus glutinosa) in Mecklenburg-Western Pomerania. In: Claessens, H. A. Oosterbaan, P. Savill, J. Rondeux, 2010. A review of the characteristics of black alder (Alnus glutinosa (L.) Gaertn.) and their implications for silvicultural practices. Forestry 83(2): 163-175 
Lockow, K.-W., 1995. Neue Ertragstafels für die Roterle. Der Wald 45 (8): 268-271.

Mitscherlich, G., 1945. Schwartzerle-Ertragstafeln (starke durchforstung). In: Schober , R., 1987. Ertragstafeln wichtiger Baumarten. Dritte Auflage, J.D. Sauerländer's Verlag, Frankfurt a. M.

Pienaar, L.V., \& K.J. Turnbull, 1973. The Chapman-Richards generalization of von Bertallanffy's growth model for basal area growth and yield in even-aged stands. Forest Science 19: 2-22.

Schober, R., 1987. Ertragstafeln wichtiger Baumarten. Dritte Auflage, J.D. Sauerländer's Verlag, Frankfurt a. M.

Schoonderwoerd, H., J.P.G. de Klein en J.N. van de Schee, 1991. Massatabellen voor zwarte els, beuk, es en inlandse eik (bosbomen). Maatschappij Damen, Schoonderwoerd en de Klein, Rapport nr. 23.

Schumacher, F.X. \& Hall, F.S., 1933. Logarithmic expression of timber-tree volume. Journal of Agricultural Research, v.47, n.9, p.719-734.

Sopp, L. 1974. Fatömeg - szamitazi tablazatok. Mezögazdasagi Kiado, Budapest, Hungary, p. 419 p. In: Claessens, H. A. Oosterbaan, P. Savill, J. Rondeux, 2010. A review of the characteristics of black alder (Alnus glutinosa (L.) Gaertn.) and their implications for silvicultural practices. Forestry 83(2): 163-175.

Thibaut, A., H. Claessens, J. Rondeux, 2004. Site index curves for Alnus glutinosa (L.) Gaertn. In southern Belgium: effect of site on curve shape. Forestry 77(2): 157-171.

van der Werf, N.G.C. 1986. Genetische Variatie bij het Geslacht Alnus. Doktoraalscriptie / Landbouwhogeschool, Vakgroep Bosteelt ; no. 86-21.

van Goor, C.P., K.R. van Lynden, H.A. van der Meiden, 1969. Houtsoorten voor nieuwe bossen in Nederland. Meiden, Koninklijke Nederlandsche Heidemaatschappij, Arnhem.

Verweij, J.A., 1983. Een vergelijkend onderzoek naar de kieming en vestiging van twee eocotypen van zwarte els (Alnus Glutinosa (L.) Gaertn.) J.A. j., Rapport Rijksinstituut voor Onderzoek in de Bos- en Landschapsbouw "De Dorschkamp" 35. 


\section{Bijlage 1. Opbrengsttabel voor zwarte els Nederland 2018}

\section{Toelichting opbrengsttabellen}

In de kop van de opbrengsttabellen zijn een aantal standaard symbolen (IUFRO, 1959). In onderstaande tabel wordt de SI-eenheid vermeld en de betekenis van het symbool weergegeven.

\begin{tabular}{|c|c|c|}
\hline symbool & eenheid & betekenis \\
\hline Boniteit & & relatieve indeling in groeiklassen \\
\hline & $\mathrm{m}$ & Site index (opperhoogte op 50 jr.) \\
\hline$P 50$ & $m^{3} h a^{-1} j^{-1}$ & Productieklasse op 50 jr. ${ }^{1)}$ \\
\hline$t$ & j & leeftijd vanaf kieming \\
\hline$h_{\text {top }}$ & $\mathrm{m}$ & opperhoogte \\
\hline$N$ & $h a^{-1}$ & stamtal per ha \\
\hline$S \%$ & & Hart-Becking dunning-index \\
\hline G & $m^{2} h a^{-1}$ & grondvlak per ha \\
\hline$d_{g}$ & $\mathrm{~cm}$ & diameter $(1,30 \mathrm{~m})$ van de middenboom ${ }^{2)}$ \\
\hline$h_{g}$ & $\mathrm{~m}$ & hoogte van de middenboom \\
\hline$V$ & $m^{3} h a^{-1}$ & volume per ha ${ }^{3)}$ \\
\hline$I c_{G}$ & $m^{2} h a^{-1} j^{-1}$ & lopende grondvlakbijgroei per ha per jaar op leeftijd $t$ jaar \\
\hline$I c_{V}$ & $m^{2} h a^{-1} j^{-1}$ & lopende volumebijgroei per ha per jaar op leeftijd $t$ jaar \\
\hline $\operatorname{Im} m_{G}$ & $m^{3} h a^{-1} j^{-1}$ & gemiddelde grondvlakbijgroei per ha per jaar tot op leeftijd $t$ jaar \\
\hline $\operatorname{Im}_{V}$ & $m^{3} h a^{-1} j^{-1}$ & gemiddelde volumebijgroei per ha per jaar tot op leeftijd $t$ jaar \\
\hline
\end{tabular}

1) gemiddelde productie, inclusief dunning maar exclusief sterfte (volumebijgroei) per ha tot op leeftijd 50 jaar

2) boom met gemiddeld boomgrondvlak en boomvolume

3) Het volume is gedefinieerd als het spilhoutvolume met schors. 


\section{Explanation yield tables}

In the header of the yield tables a number of standard symbols (IUFRO, 1959) are used. In the table below the SI units and the meaning of the symbols are given.

\begin{tabular}{|c|c|c|}
\hline symbol & unit & meaning \\
\hline Site class & & relative partition in site classes \\
\hline$h_{50}$ & $\mathrm{~m}$ & Site index (top height at $50 \mathrm{yr}$.) \\
\hline P50 & $\mathrm{m}^{3} \mathrm{ha}^{-1} \mathrm{yr}^{-1}$ & Production class at $50 \mathrm{yr} .{ }^{1)}$ \\
\hline$t$ & j & age since germination \\
\hline$h_{\text {top }}$ & $\mathrm{m}$ & top height \\
\hline$N$ & ha-1 & Number of stems per ha \\
\hline$S \%$ & & S\% (Hart-Becking spacing index) \\
\hline$G$ & $\mathrm{~m}^{2} \mathrm{ha}^{-1}$ & Basal area per ha \\
\hline$d_{g}$ & $\mathrm{~cm}$ & diameter $(1,30 \mathrm{~m})$ of the basal area mean tree \\
\hline$h_{g}$ & $\mathrm{~m}$ & height of the basal area mean tree \\
\hline$V$ & $m^{3} h a^{-1}$ & volume per ha ${ }^{2)}$ \\
\hline$I c_{G}$ & $m^{2} h a^{-1} \mathrm{yr}^{-1}$ & current basal area increment per ha per year at age $t$ \\
\hline$I c_{V}$ & $m^{2} h a^{-1} \mathrm{yr}^{-1}$ & current volume increment per ha per year at age $t$ \\
\hline$I m_{G}$ & $m^{3} h a^{-1} \mathrm{yr}^{-1}$ & mean basal area increment per ha per year until age $t$ \\
\hline $\operatorname{Im}_{V}$ & $\mathrm{~m}^{3} \mathrm{ha}^{-1} \mathrm{yr}^{-1}$ & mean volume increment per ha per year until age $t$ \\
\hline
\end{tabular}

1) Mean production, including thinning but excluding mortality (volume increment) per ha until age $50 \mathrm{yr}$.

2) The volume is defined as the stem volume over bark. 
Zwarte els Nederland 2018

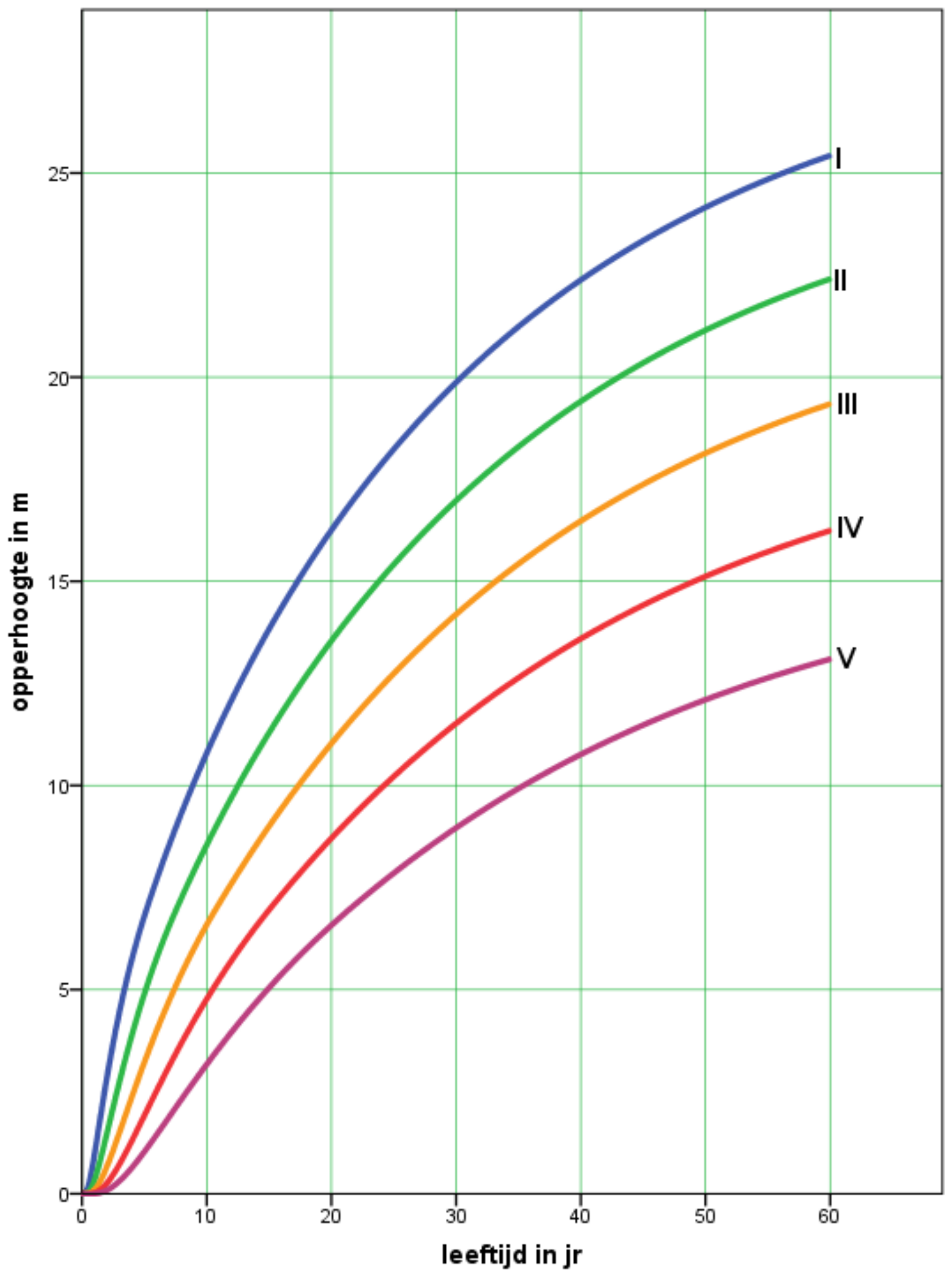




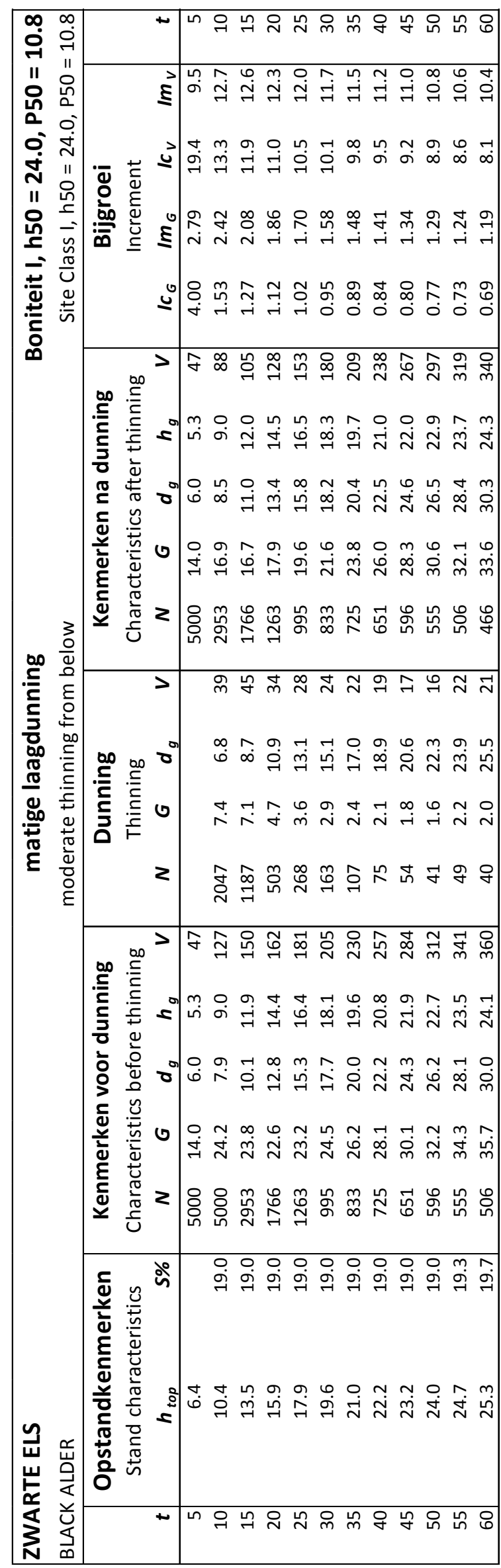




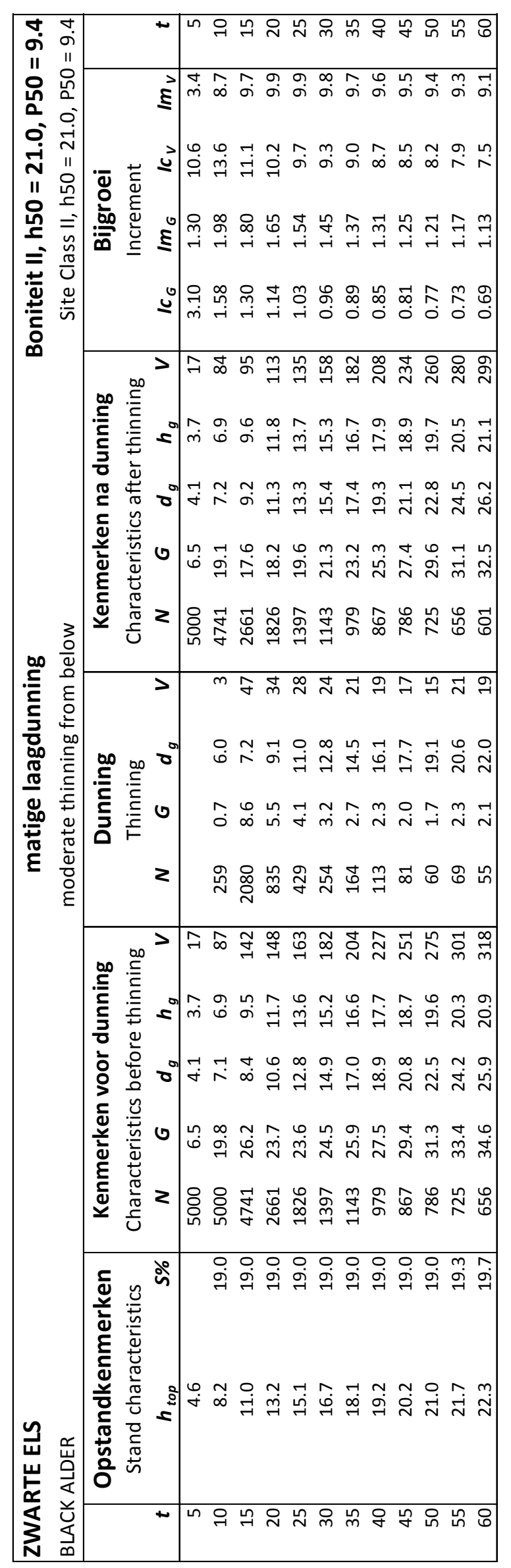




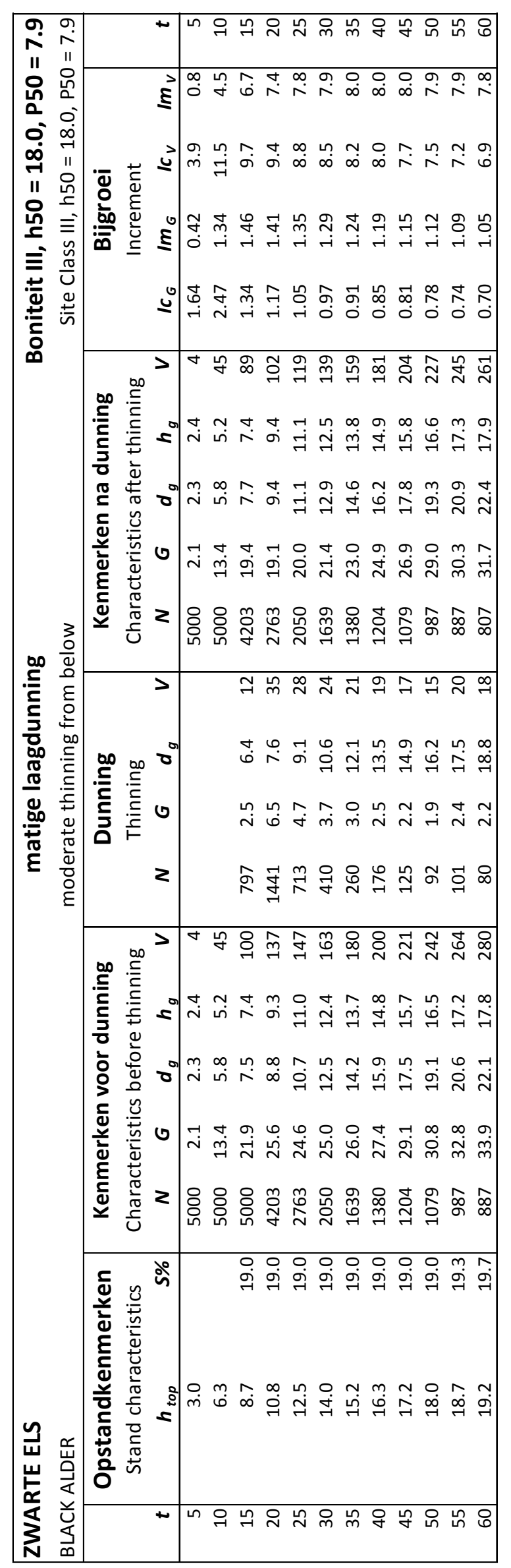




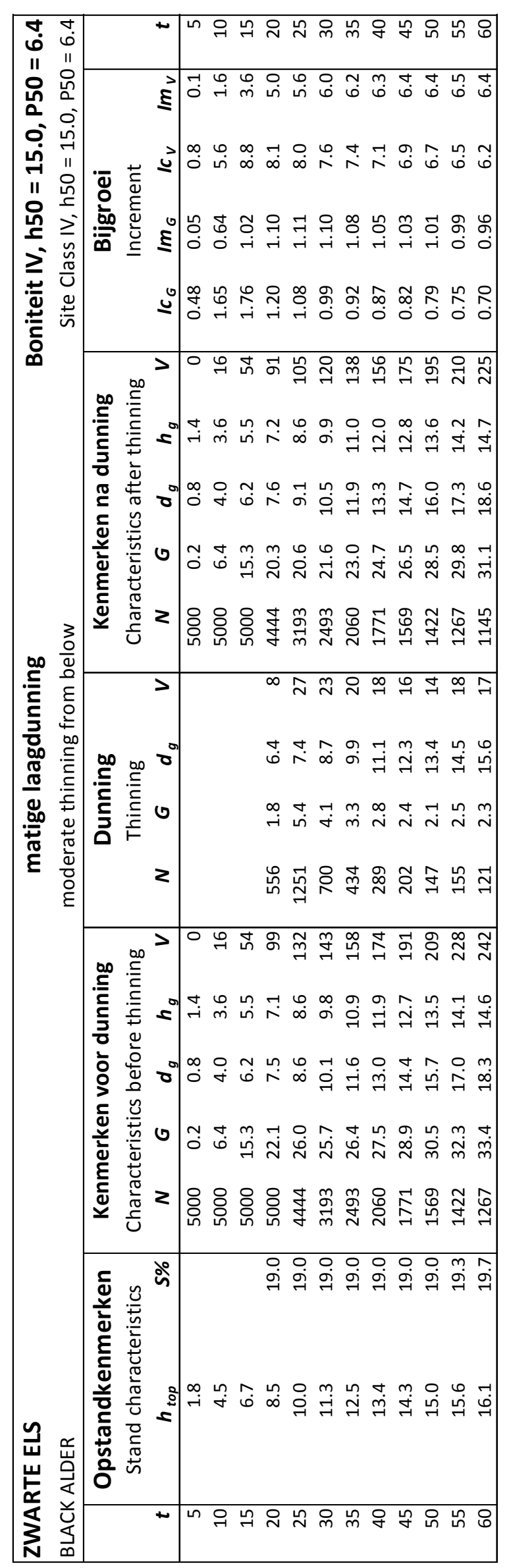




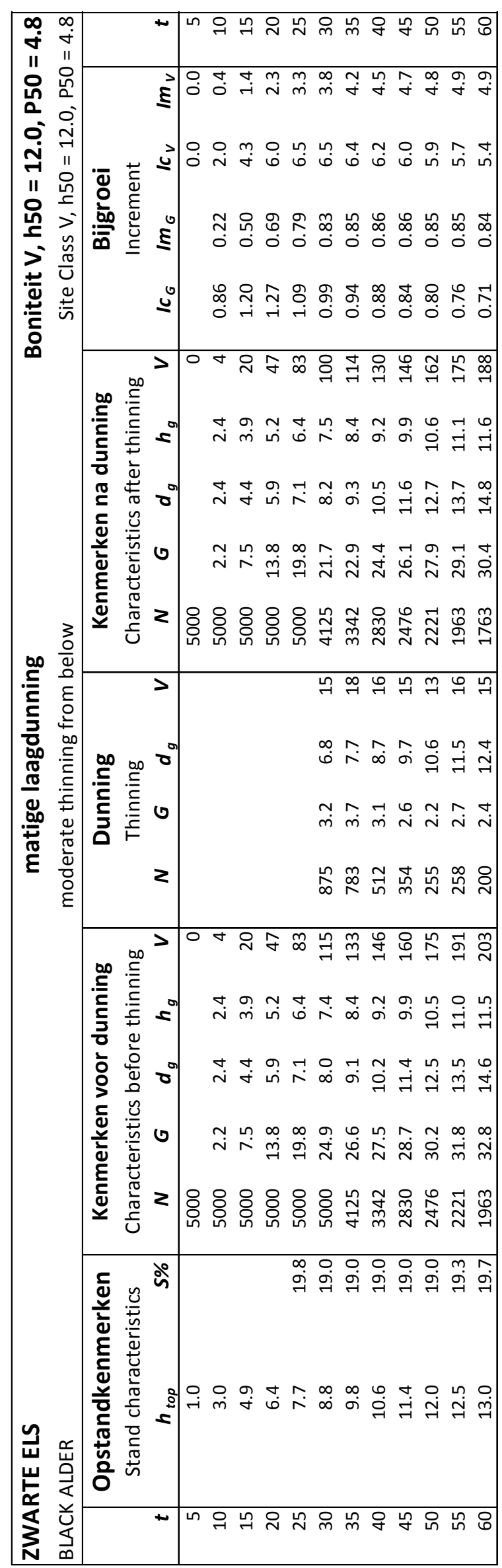

